Defining the link between indoor environment and workplace productivity in a modern UK office building

Rajat Gupta*, Alastair Howard and Sahar Zahiri

Low Carbon Building Research Group, School of Architecture, Oxford Brookes University, Oxford, United Kingdom

*rgupta@brookes.ac.uk

Number of words: 6450 


\title{
Defining the link between indoor environment and workplace productivity in a modern UK office building
}

\begin{abstract}
Most studies on the link between indoor environments and productivity have been conducted in controlled, static conditions often unrepresentative of the real world. This paper uses a case-study-based, real-world approach to empirically investigate the link between indoor environment and workplace productivity in a mechanically-ventilated office environment in southern England. Evidence gathered during the baseline period was used to implement two interventions limiting peak temperature and $\mathrm{CO}_{2}$ concentrations. Environmental parameters (temperature, relative humidity, $\mathrm{CO}_{2}$ ) were monitored continuously. Transverse and longitudinal surveys recorded occupant perceptions of their working environment and self-reported productivity, while performance tasks provided proxy measures of worker performance in terms of cognitive ability, speed and accuracy.
\end{abstract}

Workplace productivity was perceived to decrease when occupants perceived thermal discomfort and stuffy air. Correlations with perceived changes in productivity were stronger for perceived rather than measured environmental conditions and for perceived air quality rather than either measured $\mathrm{RH}$ or $\mathrm{CO}_{2}$ concentration. This implies that occupants' subjective feelings can impact their perceived productivity more than objective environmental conditions.

Furthermore median task scores were $15 \%$ lower when conducted at $\mathrm{CO}_{2}$ levels above $800 \mathrm{ppm}$ compared to below $800 \mathrm{ppm}$. Insights from the study can help to optimise indoor office environments and improve workplace productivity.

Keywords: building performance, productivity, indoor environment, office, survey

\section{Introduction}

Workplace productivity has been defined as a measure of how well resources are used to achieve a goal (BCO 2017). It has become increasingly recognised as playing a significant role in the economic output of both individual companies and nations. In the 
UK, research suggests that workplace productivity is as much as $16 \%$ lower than the G7 average (the G7 consisting of Canada, France, Germany, Italy, Japan, the UK and the USA, the group of countries with the largest and most advanced economies in the world) (ONS 2018) and that this deficit could be reduced by around 3\% through improvements to the indoor environment (BCO 2017), which would be hugely significant in financial terms. When around $90 \%$ of an organisation's costs relate to its staff (Alker et al. 2014; UKGBC 2017), the importance of improving productivity becomes clear.

Negative impacts on productivity such as poor health and sickness cost UK employers upwards of $£ 9$ billion a year (ONS 2014), while costs associated with low productivity due to presenteeism (turning up for work when ill) could be even greater. Poor health outcomes including musculoskeletal complications (Coggon et al. 2013), cardiovascular disease (Smith et al. 2016), and sick building syndrome (Shahzad et al. 2016) have all been associated with spending prolonged periods of time in office environments. The health, wellbeing and productivity of employees could all be improved through improvements to office environments.

Certain indoor environmental quality (IEQ) parameters in office buildings have been shown to influence workers' productivity (Alker et al. 2014). There are currently, however, no clearly defined parameters to produce optimal indoor conditions in mechanically ventilated office environments. Intervention and office-based studies that have shown an increase in productivity from improved indoor environment have focussed on tightly controlled individual indoor environment elements which do not reflect the dynamic real office settings which experience varying temperature, relative humidity (RH), ventilation rates, and air pollutants over the course of a day. Gathering and interpreting data collected in office environments has additional challenges, 
including isolating the effects of temperature from air quality; outside views from daylighting; and distracting noise versus beneficial background noise. Office design, layout and biophilia have also been shown to influence productivity and interaction with the indoor environment (Browning 2016).

This paper adopts a case study-based real-world approach to empirically investigate the link between indoor environment and workplace productivity using mixed methods (environmental monitoring, surveys and performance tasks) in a mechanically-ventilated office environment in southern England. A range of environmental parameters (indoor air temperature, $\mathrm{RH}$ and $\mathrm{CO}_{2}$ levels alongside outdoor temperature and $\mathrm{RH}$ ) were monitored continuously for nineteen months. A transverse Building Use Studies (BUS) survey (BUS 2019) was conducted in April 2017 to provide an overview of occupants' perception of their working environment. During the monitoring period, longitudinal online surveys recorded occupant perceptions of their working environment, thermal comfort and self-reported productivity, while performance tasks were designed to objectively measure productivity.

\section{Evidence to date}

The recommended temperature range for Category II mechanically ventilated office buildings is $22-25^{\circ} \mathrm{C}$ in summer and $21-23^{\circ} \mathrm{C}$ in winter (CIBSE 2015). These figures, based on research into the effects of temperature on health and comfort, imply that within these ranges there is no negative impact on occupant health and comfort. For naturally ventilated buildings, the indoor temperature is more strongly dependent on the outdoor temperature, whereas mechanically ventilated and air-conditioned buildings are designed to provide indoor conditions which are much more independent of outdoor 
conditions.

Studies on the relationship between indoor environment and occupant productivity, health and comfort have found negative factors such as high temperatures or high levels of $\mathrm{CO}_{2}$ to be generally more obvious than positive factors (i.e. the optimum conditions to enable improvements in health and comfort or increases in productivity) (e.g. (Witterseh, Wyon, and Clausen 2004; Fang et al. 2004; Allen et al. 2015). Further studies have therefore sought to more fully understand these relationships. Summaries of selected studies investigating the influence of indoor environmental conditions on comfort and productivity are given in Table 1.

Table 1 Summary of selected, recent studies that investigated the links between IEQ parameters on workplace performance in mechanically ventilated offices and climate chambers.

\begin{tabular}{|c|c|c|c|}
\hline Study & $\begin{array}{l}\text { Study type and } \\
\text { location }\end{array}$ & Procedure & Results \\
\hline $\begin{array}{l}\text { Al Horr et al. } \\
\text { (2016) }\end{array}$ & $\begin{array}{l}\text { Review of over } \\
300 \text { papers } \\
\text { focussed on indoor } \\
\text { environment, } \\
\text { occupant comfort, } \\
\text { productivity in } \\
\text { green buildings }\end{array}$ & $\begin{array}{l}\text { Reviewed existing } \\
\text { literature to } \\
\text { understand the } \\
\text { relationship between } \\
\text { indoor environmental } \\
\text { and occupant } \\
\text { productivity }\end{array}$ & $\begin{array}{l}\text { IEQ factors } \\
\text { influencing } \\
\text { occupant } \\
\text { productivity in } \\
\text { offices covered } 8 \\
\text { interacting } \\
\text { categories: IAQ and } \\
\text { ventilation; thermal } \\
\text { comfort; lighting } \\
\text { and daylighting; } \\
\text { noise and acoustics; } \\
\text { office layout; } \\
\text { biophilia and views; } \\
\text { look and feel; } \\
\text { location and } \\
\text { amenities }\end{array}$ \\
\hline Allen et al (2015) & $\begin{array}{l}\text { Intervention study, } \\
\text { climate chamber, } \\
\text { USA }(n=24)\end{array}$ & $\begin{array}{l}\text { Participants exposed } \\
\text { to different levels of } \\
\mathrm{CO}_{2} \text {, VOC and } \\
\text { ventilation }\end{array}$ & $\begin{array}{l}\text { Increasing } \mathrm{CO}_{2} \text { by } \\
400 \mathrm{ppm} \text { and VOC } \\
\text { by } 0.5 \mathrm{mg} / \mathrm{m}^{3} \\
\text { decreased cognitive } \\
\text { function by } 13-21 \% \text {. } \\
\text { Increasing } \\
\text { ventilation rates } \\
\text { improved cognitive } \\
\text { function by } 18 \%\end{array}$ \\
\hline Fang et al (2004) & $\begin{array}{l}\text { Intervention study, } \\
\text { mechanically } \\
\text { ventilated office, }\end{array}$ & $\begin{array}{l}\text { Participants exposed } \\
\text { to different } \\
\text { combinations of }\end{array}$ & $\begin{array}{l}\text { Increase in SBS } \\
\text { symptoms and } \\
\text { difficulty in thinking }\end{array}$ \\
\hline
\end{tabular}




\begin{tabular}{|c|c|c|c|}
\hline & Denmark $(n=30)$ & $\begin{array}{l}\text { temperature and } \mathrm{RH} \\
\left(20^{\circ} \mathrm{C} / 40 \% ; 23^{\circ} \mathrm{C} /\right. \\
\left.50 \% ; 26^{\circ} \mathrm{C} / 60 \%\right) \\
\text { and ventilation rates } \\
(3.5 \text { and } 101 / \mathrm{s} / \mathrm{p})\end{array}$ & $\begin{array}{l}\text { at higher } \\
\text { temperature. } \\
\text { Performance not } \\
\text { significantly } \\
\text { affected by } \\
\text { temperature or } \\
\text { humidity }\end{array}$ \\
\hline $\begin{array}{l}\text { Federspiel et al } \\
\text { (2004) }\end{array}$ & $\begin{array}{l}\text { Observation study, } \\
\text { mechanically } \\
\text { ventilated call } \\
\text { centre, USA }\end{array}$ & $\begin{array}{l}\text { Average call handling } \\
\text { time, temperature, } \\
\mathrm{RH} \text { and } \mathrm{CO}_{2} \text { recorded } \\
\text { for almost three } \\
\text { months }\end{array}$ & $\begin{array}{l}\text { Call handling times } \\
\text { increased as } \\
\text { difference in indoor } \\
\text { and outdoor } \mathrm{CO}_{2} \\
\text { increased above } \\
75 \mathrm{ppm} \text {. } \\
\text { Temperatures } \\
\text { between } 21.7 \text { and } \\
24.5^{\circ} \mathrm{C} \text { had no effect } \\
\text { on performance }\end{array}$ \\
\hline Gupta et al (2016) & $\begin{array}{l}\text { Meta-analysis of } \\
\text { low-energy office } \\
\text { buildings, UK } \\
(\mathrm{n}=50)\end{array}$ & $\begin{array}{l}\text { Analysis of occupant } \\
\text { surveys conducted in } \\
\text { a variety of non- } \\
\text { domestic workspaces }\end{array}$ & $\begin{array}{l}\text { Perceived } \\
\text { productivity } \\
\text { increased due to } \\
\text { perceived } \\
\text { environmental } \\
\text { conditions in over } \\
\text { half of workspaces. }\end{array}$ \\
\hline Kajtar et al (2003) & $\begin{array}{l}\text { Intervention study, } \\
\text { climate chamber, } \\
\text { Hungary }(n=10)\end{array}$ & $\begin{array}{l}\text { Participants exposed } \\
\text { to different } \mathrm{CO}_{2} \\
\text { levels }(600,1500, \\
3000 \text { and } 4000 \mathrm{ppm})\end{array}$ & $\begin{array}{l}\text { Significantly more } \\
\text { misspelled words as } \\
\mathrm{CO}_{2} \text { levels increased } \\
\text { from } 600 \mathrm{ppm} \text { to } \\
3000 \text { and } 4000 \mathrm{ppm}\end{array}$ \\
\hline Lan et al (2011) & $\begin{array}{l}\text { Intervention study, } \\
\text { mechanically } \\
\text { ventilated office, } \\
\text { Denmark }(n=12)\end{array}$ & $\begin{array}{l}\text { Participants } \\
\text { completed tasks at } \\
\text { two different thermal } \\
\text { conditions ( } 22 \text { and } \\
30^{\circ} \mathrm{C} \text { ) }\end{array}$ & $\begin{array}{l}\text { Performance in } 8 \\
\text { out of } 9 \text { tasks } \\
\text { decreased in high } \\
\text { temperature. At } \\
30^{\circ} \mathrm{C} \text { in text typing, } \\
\text { more characters } \\
\text { were typed but more } \\
\text { mistakes were made }\end{array}$ \\
\hline $\begin{array}{l}\text { Park and Yoon } \\
\text { (2011) }\end{array}$ & $\begin{array}{l}\text { Intervention study, } \\
\text { climate chamber, } \\
\text { South Korea } \\
(n=24)\end{array}$ & $\begin{array}{l}\text { Participants exposed } \\
\text { to three different } \\
\text { ventilation rates }(5 \text {, } \\
10,201 / \mathrm{s} / \mathrm{p})\end{array}$ & $\begin{array}{l}\text { Increasing } \\
\text { ventilation rate from } \\
5 \text { to } 20 \mathrm{l} / \mathrm{s} / \mathrm{p} \\
\text { improved } \\
\text { calculation accuracy } \\
\text { by } 5 \% \text { and typing } \\
\text { and memorisation } \\
\text { accuracy by } 2.5 \%\end{array}$ \\
\hline Satish et al (2012) & $\begin{array}{l}\text { Intervention study, } \\
\text { climate chamber, } \\
\text { USA }(n=22)\end{array}$ & $\begin{array}{l}\text { Participants exposed } \\
\text { to different } \mathrm{CO}_{2} \\
\text { levels }(600,1000 \text { and } \\
2500 \mathrm{ppm})\end{array}$ & $\begin{array}{l}\text { Decision making } \\
\text { performance } \\
\text { decreased as } \mathrm{CO}_{2} \\
\text { levels increased } \\
\text { from } 600 \mathrm{ppm} \text { to }\end{array}$ \\
\hline
\end{tabular}




\begin{tabular}{|c|c|c|c|}
\hline & & & 1000 and $2500 \mathrm{ppm}$ \\
\hline $\begin{array}{l}\text { Seppänen et al. } \\
(2006)\end{array}$ & $\begin{array}{l}\text { Review of studies } \\
\text { (11 field-based, } 9 \\
\text { climate-chamber } \\
\text { based) }\end{array}$ & $\begin{array}{l}\text { Meta-analysis } \\
\text { conducted on } \\
\text { published studies } \\
\text { which investigated } \\
\text { the influence of } \\
\text { temperature on } \\
\text { performance }\end{array}$ & $\begin{array}{l}\text { Temperature range } \\
\text { for maximum } \\
\text { performance found } \\
\text { to be } 21-24^{\circ} \mathrm{C} \text { with a } \\
2 \% \text { decrease in } \\
\text { performance per } 1^{\circ} \mathrm{C} \\
\text { increase in } \\
\text { temperature above } \\
25^{\circ} \mathrm{C}\end{array}$ \\
\hline $\begin{array}{l}\text { Tenabe et al. } \\
(2015)\end{array}$ & $\begin{array}{l}\text { Intervention study, } \\
\text { climate chamber, } \\
\text { Japan }(n=11)\end{array}$ & $\begin{array}{l}\text { Participants exposed } \\
\text { to } 5 \text { scenarios } \\
\text { combining } \\
\text { temperature ( } 25.5 \text { and } \\
28.5^{\circ} \mathrm{C} \text { ), clothing } \\
\text { (with and without } \\
\text { suits), and cooling } \\
\text { items (fan, air-con' } \\
\text { shirt, mesh chair) }\end{array}$ & $\begin{array}{l}\text { Actual air } \\
\text { temperature } \\
\text { correlated poorly } \\
\text { with self-estimated } \\
\text { performance, } \\
\text { whereas perceived } \\
\text { thermal satisfaction } \\
\text { correlated well with } \\
\text { self-estimated } \\
\text { performance }\end{array}$ \\
\hline $\begin{array}{l}\text { Tham and Willem } \\
\text { (2005) }\end{array}$ & $\begin{array}{l}\text { Intervention study, } \\
\text { mechanically } \\
\text { ventilated call } \\
\text { centre, Singapore } \\
(\mathrm{n}=56)\end{array}$ & $\begin{array}{l}\text { Call times measured } \\
\text { at different } \\
\text { temperatures }(22.5 \\
\left.\text { and } 24.5^{\circ} \mathrm{C}\right) \text { and } \\
\text { ventilation rates ( } 5 \\
\text { and } 10 \mathrm{l} / \mathrm{s} / \mathrm{p})\end{array}$ & $\begin{array}{l}\text { Increasing } \\
\text { ventilation rate to } 10 \\
1 / \mathrm{s} / \mathrm{p} \text { reduced call } \\
\text { talk time by } 11 \% \text {. } \\
\text { Reducing } \\
\text { temperature to } \\
22.5^{\circ} \mathrm{C} \text { increased } \\
\text { call talk time by } \\
15.5 \%(\text { at } 10 \mathrm{l} / \mathrm{s} / \mathrm{p})\end{array}$ \\
\hline $\begin{array}{l}\text { Vimalanathan and } \\
\text { Babu (2014) }\end{array}$ & $\begin{array}{l}\text { Intervention study, } \\
\text { climate chamber, } \\
\text { India }(n=10)\end{array}$ & $\begin{array}{l}\text { Participants exposed } \\
\text { to different thermal } \\
\text { conditions }(17,21 \\
\left.\text { and } 28^{\circ} \mathrm{C}\right) \text { and light } \\
\text { conditions ( } 500,700 \\
\text { and } 1000 \text { lux })\end{array}$ & $\begin{array}{l}\text { Temperature and } \\
\text { light accounted for } \\
39 \% \text { and } 20 \% \\
\text { variation in } \\
\text { performance } \\
\text { respectively. } \\
\text { Optimum conditions } \\
\left(21^{\circ} \mathrm{C} \text { and } 1000 \text { lux }\right) \\
\text { improved worker } \\
\text { productivity }\end{array}$ \\
\hline $\begin{array}{l}\text { Wargocki et al } \\
\text { (1999) }\end{array}$ & $\begin{array}{l}\text { Intervention study, } \\
\text { mechanically } \\
\text { ventilated office, } \\
\text { Denmark }(n=30)\end{array}$ & $\begin{array}{l}\text { Participants exposed } \\
\text { to three different } \\
\text { ventilation rates }(3, \\
10,30 \mathrm{l} / \mathrm{s} / \mathrm{p})\end{array}$ & $\begin{array}{l}\text { Overall performance } \\
\text { increased by } 1.7 \% \\
\text { for every two-fold } \\
\text { increase in } \\
\text { ventilation rate from } \\
3-301 / \mathrm{s} / \mathrm{p}\end{array}$ \\
\hline $\begin{array}{l}\text { Witterseh et al } \\
(2004)\end{array}$ & $\begin{array}{l}\text { Intervention study, } \\
\text { mechanically } \\
\text { ventilated office, } \\
\text { Denmark }(n=30)\end{array}$ & $\begin{array}{l}\text { Participants } \\
\text { completed tasks } \\
\text { whilst exposed to } 3 \\
\text { air temperatures } \\
\left(22^{\circ} \mathrm{C}, 26^{\circ} \mathrm{C} \text { and }\right. \\
\end{array}$ & $\begin{array}{l}3 \% \text { decrease in } \\
\text { performance in } \\
\text { calculation tasks at } \\
\text { higher noise level. } \\
56 \% \text { more mistakes }\end{array}$ \\
\hline
\end{tabular}




\begin{tabular}{|l|l|l|}
\hline & $\begin{array}{l}\left.30^{\circ} \mathrm{C}\right) \text { and } 2 \text { noise } \\
\text { levels (35dBA and } \\
55 \mathrm{dBA})\end{array}$ & in task at highest \\
& temperature \\
\hline
\end{tabular}

Indoor temperature was found to significantly influence occupant productivity in several studies (Witterseh, Wyon, and Clausen 2004; Lan et al. 2011; Tham and Willem 2005; Seppanen, Fisk, and Lei 2006). Climate chamber studies have also identified temperature as accounting for as much as $40 \%$ of the variation in task performance, with both high temperatures $\left(28^{\circ} \mathrm{C}\right)$ and low temperatures $\left(17^{\circ} \mathrm{C}\right)$ showing a negative correlation with performance (Vimalanathan and Babu 2014). Interestingly, another climate chamber study found only a poor correlation between measured air temperature and perceived performance, but a much stronger correlation between thermal comfort and perceived performance (Tanabe, Haneda, and Nishihara 2015). Several studies (Lan et al. 2011; Allen et al. 2015) found a discrepancy between the temperature ranges for optimal thermal comfort and optimum productivity, the temperature range identified as thermally comfortable being different to the range that produced the best productivity. $\mathrm{CO}_{2}$ concentration (either measured directly in parts/million or indirectly as ventilation rates - litres/second/person) has also featured in several studies investigating occupant performance. Studies found that higher ventilation rates/lower $\mathrm{CO}_{2}$ concentrations) correlated with a more productive workforce (Tham and Willem 2005; Wargocki et al. 1999; Park and Yoon 2011; Allen et al. 2015; Satish et al. 2012; Kajtar, Herczeg, and Lang 2003; Federspiel et al. 2004).

Meta-analysis of published studies investigating the links between indoor environment and occupant productivity revealed eight IEQ factors that influenced occupant productivity in an office environment (Al Horr et al. 2016). Alongside measurable parameters (indoor air quality and ventilation; thermal comfort; lighting and daylighting; noise and acoustics), were more subjective parameters (office layout; 
biophilia and views; look and feel; location and amenities). There was significant interaction and crossover between these factors (e.g. levels of daylighting interacting with thermal comfort; lower temperatures leading to improved perception of air quality).

Meta-study of Building User Studies (BUS) surveys of 43 low-energy nondomestic buildings (1,170 respondents) in the UK has revealed that more than half of the buildings reported an increase in perceived productivity due to the environmental conditions perceived by the occupants (Gupta, Cudmore, and Bruce-Konuah 2016). The BUS methodology survey asks respondents questions about their experience of their workplace (BUS methodology, 2019). Statistical analysis of the BUS survey data from the sample of 1.1170 responses covering 43 buildings was undertaken. Particular focus was given to identifying which independent variables had the most significant links to perceived change in productivity (defined in the survey by the question, "Please estimate how you think your productivity at work is decreased or increased by the environmental conditions in the building", with responses on a scale from " $-40 \%$ or more" to " $+40 \%$ or more" in $10 \%$ increments).

It was found that several independent variables had statistically significant connections (correlations and covariance) with the occupants' perceived change in productivity (Table 2). The strongest correlations with perceived change in productivity came from "Comfort" ("All things considered, how do you rate the overall comfort of the building environment?" on a scale from 1 (unsatisfactory) to 7 (satisfactory), Spearman $\mathrm{R}=0.52$ ), "Health" ("Do you feel less or more healthy when you are in the building?" on a scale from 1 (less healthy) to 7 (more healthy), Spearman $\mathrm{R}=0.44$ ) and "Conditions in winter" ("How would you describe typical working conditions in your normal work area in winter?" on a scale from 1 (unsatisfactory overall) to 7 
(satisfactory overall), Spearman $\mathrm{R}=0.42$ ). How well the buildings' facilities met the needs of the workers, lighting and control of heating all showed weaker but still statistically significant correlations with perceived change in productivity. Interestingly occupants who said that they had changed their behaviour because of conditions in the building were found to be statistically more likely to rate changes to their productivity more negatively.

Table 2 Spearman correlations between BUS independent variables and perceived change in productivity $(\mathrm{N}=1170)$.

\begin{tabular}{|c|c|}
\hline Variable & 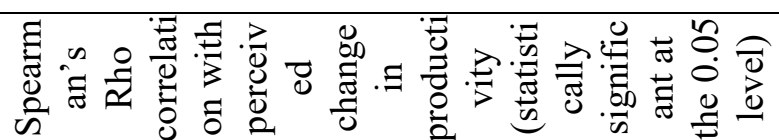 \\
\hline Comfort & 0.52 \\
\hline Health & 0.44 \\
\hline Conditions in winter (overall) & 0.42 \\
\hline Facilities & 0.40 \\
\hline Lighting (natural) & 0.24 \\
\hline Control (heating) & 0.22 \\
\hline
\end{tabular}

It is worth noting that although correlations and covariance do not necessarily equate to causation, findings from this meta-study provides useful insights into the potential relationship between perceived indoor environmental conditions and perceived change in productivity, something that will investigated further in this study. Such subjective data will be cross-related with objective data on indoor environment and worker performance to empirically investigate the link between perceived indoor environment and perceived productivity, as well as measured indoor environment and worker performance in terms of cognitive capability, speed and accuracy.

\section{Methodology and case study}

The methodology adopted in the study had a three-pronged approach: 
- Physical monitoring of indoor and outdoor environment using data loggers, recording temperature, $\mathrm{RH}$ and $\mathrm{CO}_{2}$ concentration at five-minute intervals from March 2017 to September 2018;

- Occupant surveys (transverse and longitudinal) as a measure of perceived productivity;

- Performance tasks (productivity tests) as a proxy measure of worker performance in terms of their cognitive capability, speed and accuracy.

Physical monitoring was implemented using data loggers located throughout the case study workspaces (Table 3). The workspaces were divided into 20 zones, each zone consisting of between six and sixteen workstations and approximately 40 to 90 square metres, with each one monitored. This provided granularity in the data and allowed occupant responses to be cross-related to concurrent indoor environmental conditions. Within the case study workspace, individuals may have had differing job descriptions, but all fell under the umbrella of computer/desk-based office work. Throughout the study, response rates for the surveys and tasks varied from one zone to the next. As responses were entirely voluntary, it was not possible to control this - respondents were a self-selecting group. However, repeating the surveys and tasks over many rounds helped to alleviate any potential bias in the responses.

Table 3 Specifications for the installed data loggers.

\begin{tabular}{|l|l|l|}
\hline Data logger & Measure & Specifications \\
\hline Yanzi Comfort by Spika & Temperature & $\begin{array}{l}\text { Range: }-20^{\circ} \mathrm{C} \text { to }+60^{\circ} \mathrm{C} \\
\text { Accuracy: } \pm 1{ }^{\circ} \mathrm{C}\end{array}$ \\
\cline { 2 - 3 } & $\mathrm{RH}$ & $\begin{array}{l}\text { Range: } 0 \% \text { to } 100 \% \mathrm{RH} \\
\text { Accuracy: } \pm 5 \% \mathrm{RH}\end{array}$ \\
\cline { 2 - 3 } & $\mathrm{CO}_{2}$ concentration & $\begin{array}{l}\text { Range: } 400 \mathrm{ppm} \text { to } 5000 \mathrm{ppm} \\
\text { Accuracy: } \pm(50 \mathrm{ppm}+5 \% \text { reading })\end{array}$ \\
\hline \multirow{2}{*}{ Yanzi Motion+ by Spika } & Temperature & $\begin{array}{l}\text { Range: }-20^{\circ} \mathrm{C} \text { to }+60^{\circ} \mathrm{C} \\
\text { Accuracy: } \pm 0.3^{\circ} \mathrm{C}\left(+5^{\circ} \mathrm{C} \text { to }+50^{\circ} \mathrm{C}\right)\end{array}$ \\
\hline
\end{tabular}




\begin{tabular}{|c|c|c|}
\hline$*$. & $\mathrm{RH}$ & $\begin{array}{l}\text { Range: } 0 \% \text { to } 100 \% \mathrm{RH} \\
\text { Accuracy: } \pm 5 \% \mathrm{RH}\end{array}$ \\
\hline 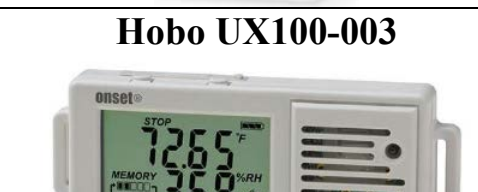 & Temperature & $\begin{array}{l}\text { Range: }-20^{\circ} \mathrm{C} \text { to }+70^{\circ} \mathrm{C} \\
\text { Accuracy: } \pm 0.21^{\circ} \mathrm{C} \text { (from } 0^{\circ} \mathrm{C} \text { to } \\
50^{\circ} \mathrm{C} \text { ) } \\
\text { Resolution: } 0.024^{\circ} \mathrm{C} \text { at } 25^{\circ} \mathrm{C}\end{array}$ \\
\hline $\begin{array}{l}\text { Limensions: } 37 \times 85 \times 15 \mathrm{~mm} \\
\text { Dimeocom }\end{array}$ & RH & $\begin{array}{l}\text { Range: } 15 \% \text { to } 95 \% \\
\text { Accuracy: } \pm 3.5 \% \text { from } 25 \% \text { to } 85 \% \\
\text { Resolution: } 0.07 \% \text { at } 25 \%\end{array}$ \\
\hline HOBO U12-012 & Temperature & $\begin{array}{l}\text { Range: }-20^{\circ} \mathrm{C}-+70^{\circ} \mathrm{C} \\
\text { Accuracy: } \pm 0.35^{\circ} \mathrm{C} \text { from } 0^{\circ} \mathrm{C} \text { to } \\
50^{\circ} \mathrm{C} \\
\text { Resolution: } 0.03^{\circ} \mathrm{C} \text { at } 25^{\circ} \mathrm{C}\end{array}$ \\
\hline $\begin{array}{l}\text { Dimensions: } \\
58 \times 74 \times 22 \mathrm{~mm}\end{array}$ & RH & $\begin{array}{l}\text { Range: } 5 \%-95 \% \\
\text { Accuracy: } \pm 2.5 \% \text { from } 10 \% \text { to } 90 \% \\
\text { Resolution: } 0.03 \%\end{array}$ \\
\hline $\begin{array}{c}\text { Tinytag } \mathrm{CO}_{2} \text {-TGE-0011 } \\
\text { Dimensions: } \\
85 \times 100 \times 26 \mathrm{~mm}\end{array}$ & $\mathrm{CO}_{2}$ concentration & $\begin{array}{l}\text { Range: } 0-5000 \mathrm{ppm} \\
\text { Accuracy: }< \pm(50 \mathrm{ppm} \text { or } 3 \% \text { of } \\
\text { measured value }) \\
\text { Resolution: } 0.1 \mathrm{ppm}\end{array}$ \\
\hline 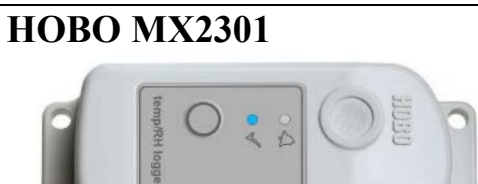 & Outdoor temperature & $\begin{array}{l}\text { Range: }-40^{\circ} \mathrm{C} \text { to }+70^{\circ} \mathrm{C} \\
\text { Accuracy: } \pm 0.25^{\circ} \mathrm{C} \text { from }-40^{\circ} \mathrm{C} \text { to } \\
0^{\circ} \mathrm{C}, \pm 0.2^{\circ} \mathrm{C} \text { from } 0^{\circ} \mathrm{C} \text { to } 70^{\circ} \mathrm{C} \\
\text { Resolution: } 0.04^{\circ} \mathrm{C}\end{array}$ \\
\hline $\begin{array}{l}\text { Dimensions: } \\
102 \times 38 \mathrm{~mm}\end{array}$ & Outdoor RH & $\begin{array}{l}\text { Range: } 0 \% \text { to } 100 \% \\
\text { Accuracy: } \pm 2.5 \% \text { from } 10 \% \text { to } 90 \% \\
\text { Resolution: } 0.05 \%\end{array}$ \\
\hline
\end{tabular}

The surveys and performance tasks were implemented over a baseline period from March to July 2017, with results used to inform the intervention designs that were implemented over two four-week periods, the first during October/November 2017 and the second during May/June 2018. Figure 1 outlines the methodological approach adopted in the project. 


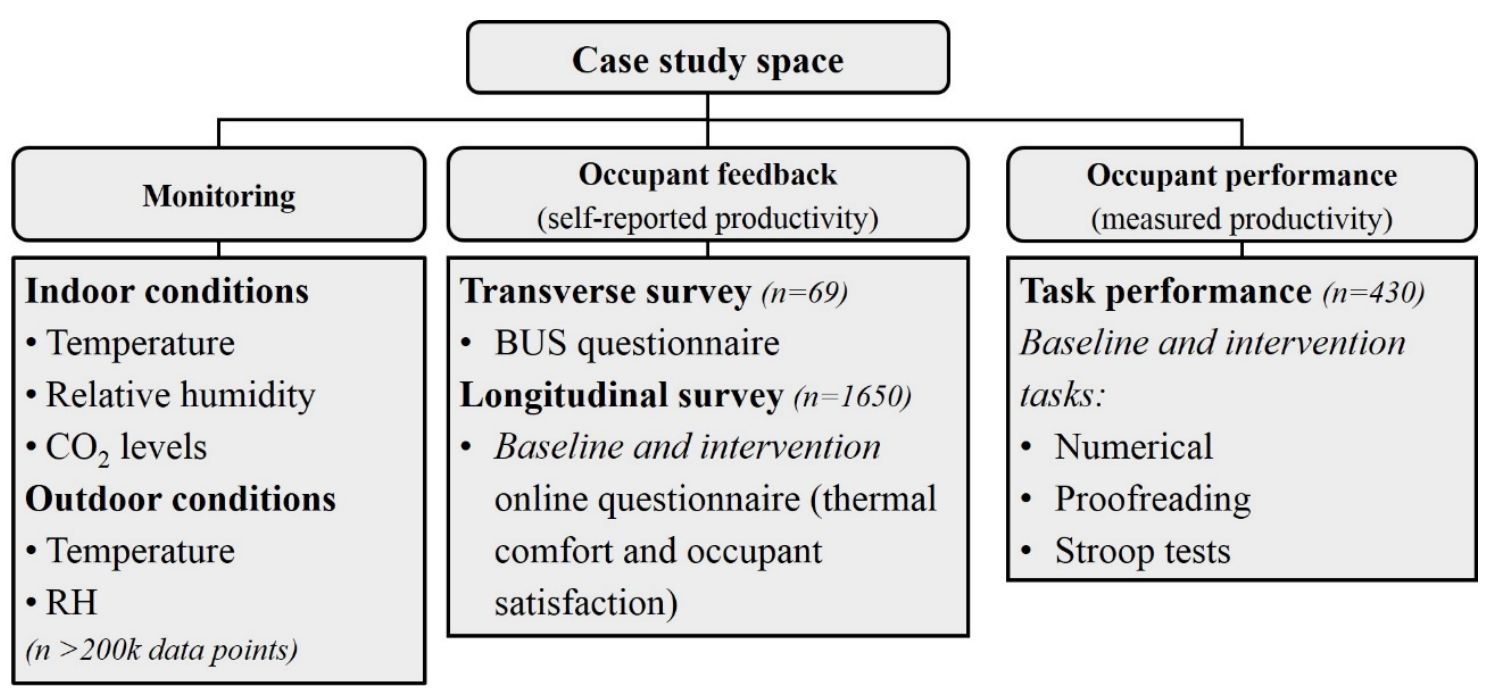

Figure 1 Methodology

The performance tasks were chosen to emulate the typical tasks occupants would undertake:

- 'Numerical' tasks consisted of 25 mentally-solvable arithmetic questions;

- 'Proofreading' tasks consisted of 4 short paragraphs of text in which respondents had to identify spelling errors;

- 'Stroop' test: an interference test where respondents had to differentiate between the colour and text of 50 words.

Screenshot examples of each of these test types are given in Figure 2. Throughout this study, the proofreading tests proved to be the most challenging of the three tests. This provided a broader spread of test scores and test durations than either the numerical or Stroop tests, but was consequently the least popular of the three tests. 


\begin{tabular}{|c|c|c|}
\hline $\begin{array}{l}36+15=24+? \\
\square 51 \\
\square 27 \\
\square 55 \\
\square 29 \\
\square 52 \\
102-89=? \\
\square 11 \\
\square 13 \\
\square 31 \\
\square 33 \\
\square 35\end{array}$ & $\begin{array}{l}\text { Identify the spelling errors in this text: } \\
\text { So he took hold of Pooh's front pause and Rabbit took hold of } \\
\text { Christopher Robin, and all Rabbit's friends and rellations took hold } \\
\text { of Rabbit, and they all pulled together... And for a long thyme Pooh } \\
\text { only said 'Ow!'... And 'Oh!'... And then, all of a sudden he said } \\
\text { 'Pop!' just if a corck were coming out of a bottle. And Christopher } \\
\text { Robin and Rabbit and all relations went head-over-heels } \\
\text { backwards ...and on top of them came Winnie-the-Pooh free! So } \\
\text { with a nod of tanks to his friends, he went on with his walk throught } \\
\text { the forest, humming proudly to himself. But Christopher Robin } \\
\text { looked after him lovingly, and said to himself, 'Silly Old Bear!' }\end{array}$ & $\begin{array}{l}\text { Select the colour of the word: } \\
\square \text { Black } \\
\square \text { Blue } \\
\square \text { Green } \\
\square \text { Red } \\
\square \text { Yellow } \\
\text { Select the colour of the word: } \\
\square \text { Black } \\
\square \text { Blue } \\
\square \text { Green } \\
\square \text { Red } \\
\square \text { Yellow }\end{array}$ \\
\hline
\end{tabular}

Figure 2 Screenshot samples of the numerical test (left), proofreading test (centre) and Stroop test (right).

\section{Case study building}

The case study building, located in a business park in southern England, is a modern office building typical of those found in the UK (Korolija et al. 2013) and which will become the normal archetype within the next decade. Images, floorplans and descriptive characteristics of the building are provided in Table 4. Facilities are managed by an onsite external facilities management company using a BMS system, with mechanical ventilation and non-openable windows: Occupants are therefore not able to control their working environment directly but can contact the facilities management team to request changes. Two open-plan administrative office areas were selected for the study, approximately similar in size and occupancy. The gender mix of occupants in this workspace (approximately 57\% male, $43 \%$ female), and the distribution of age groupings (approximately 10\% under 30, 90\% 30 and over based on the BUS questionnaire responses) was representative of a typical working office. Although there were 162 workstations within the case study offices, the mailing list for surveys and tasks consisted of 220 occupants, and the occupancy rate within the case study offices was approximately $80 \%$ during the monitored period. 
Table 4 External view of building (top left), satellite image of building (top right), floorplan of first and second floor case study areas (middle), descriptive characteristics of the case study building (bottom left) and of the case study offices (bottom right).

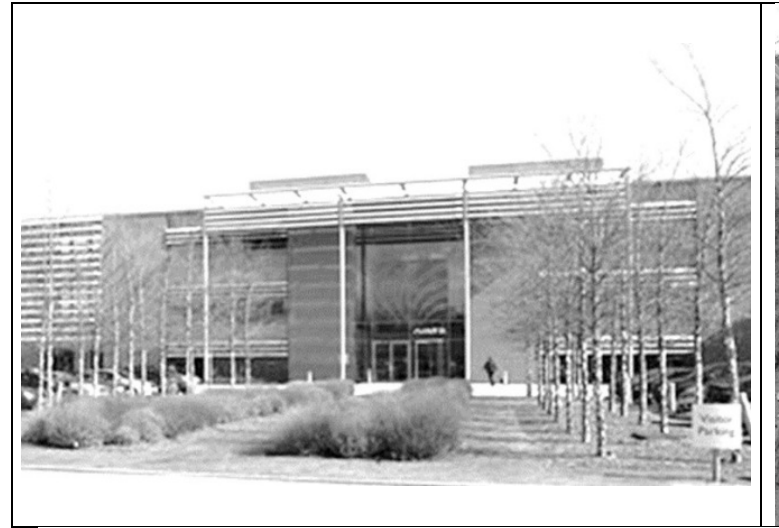

$1^{\text {st }}$ floor office area

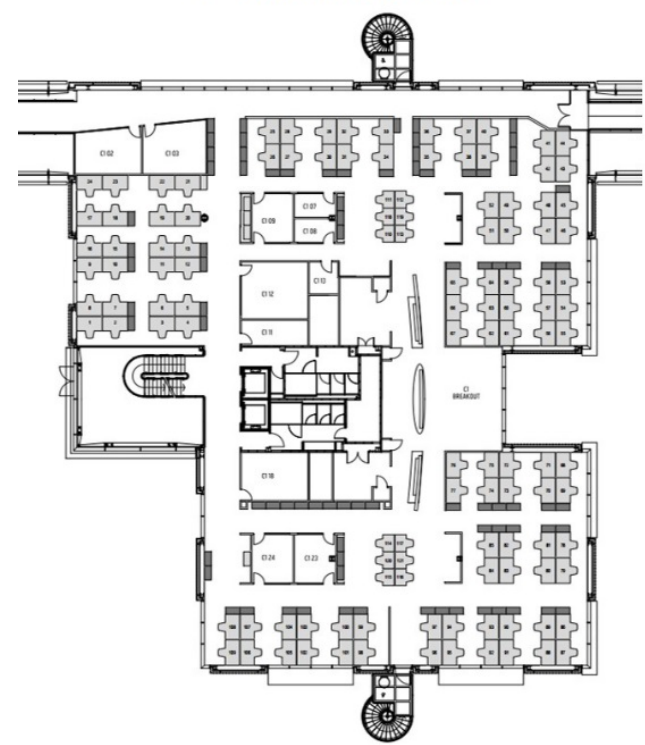

Characteristics of case study building

Location: Business park adjacent to woodland, southern England

Type of facility: Open-plan office

Date of construction: $2004-6$

Ownership: Owner occupied

Facility management: Subcontractor

Energy systems: Mains gas and grid electricity

Heating and cooling: Mechanically ventilated and heated throughout.

EPC Energy rating: C and D

Operating hours (hours space is controlled for heating/cooling): Weekdays, 07:00 -

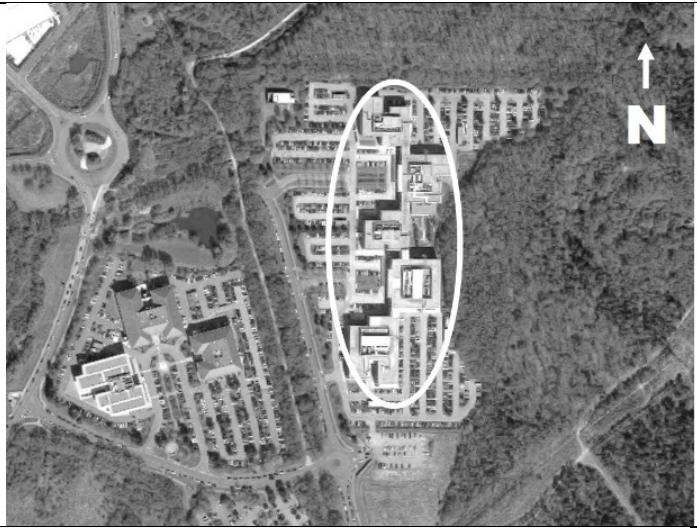

$2^{\text {nd }}$ floor office area

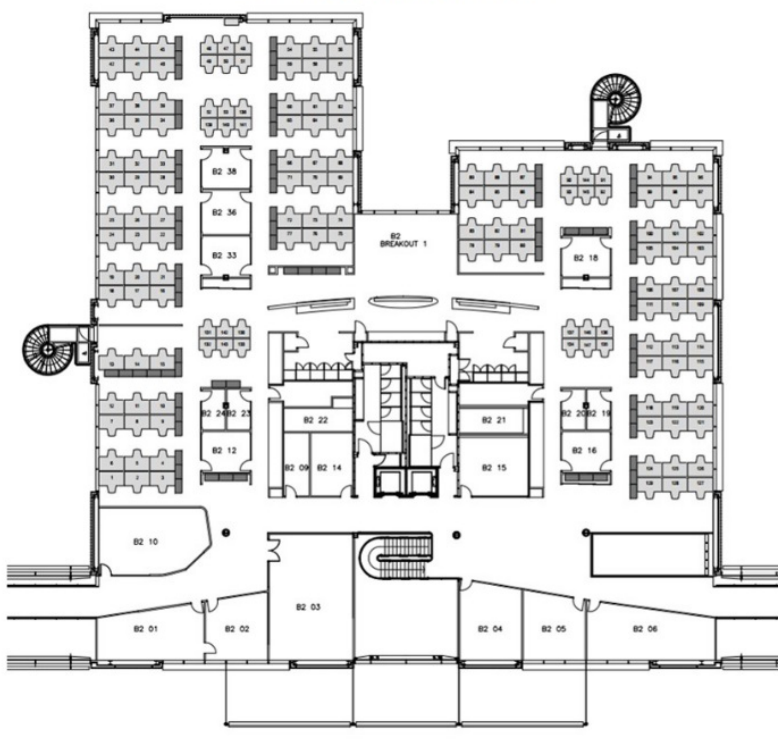

Characteristics of case study offices

Floor area: 1,900 $\mathrm{m}^{2}$ approx.

No. of workstations: 162Main tasks:

Administration

Working arrangement: Allocated desks and hot-desking.

Local control over windows: No

IT equipment: Desktops, laptops, telephones Meeting rooms: 24

Working hours: $08: 30-18: 30$ 


\section{Indoor environment: temperature, relative humidity and $\mathrm{CO}_{2}$ concentration}

Physical monitoring showed that during occupied hours (08:30 - 18:30) indoor temperatures remained within a narrow band throughout the whole nineteen months of monitoring. During the heating seasons (March-April 2017 and October 2017-April 2018 ) indoor temperatures were below the recommended $21^{\circ} \mathrm{C}$ for less than $0.3 \%$ of occupied hours. Although indoor temperatures exceeded the recommended $23^{\circ} \mathrm{C}$ for over $81 \%$ of occupied hours, they only exceeded $24^{\circ} \mathrm{C}$ and $25^{\circ} \mathrm{C}$ for $24 \%$ and $1 \%$ of occupied hours respectively. During the non-heating seasons (May-September 2017 and May-September 2018) indoor temperatures were below the recommended $22^{\circ} \mathrm{C}$ for less than $0.4 \%$ of occupied hours. Indoor temperatures exceeded the recommended $24^{\circ} \mathrm{C}$ for $51 \%$ of occupied hours and $25^{\circ} \mathrm{C}$ for $7 \%$ of occupied hours.

The boxplot of indoor temperatures by month, with the monthly average outdoor temperatures (recorded on site using an outdoor logger) during working hours also shown is presented in Figure 3. The building's heating and cooling system was able to keep the indoor temperatures within a fairly narrow band. 


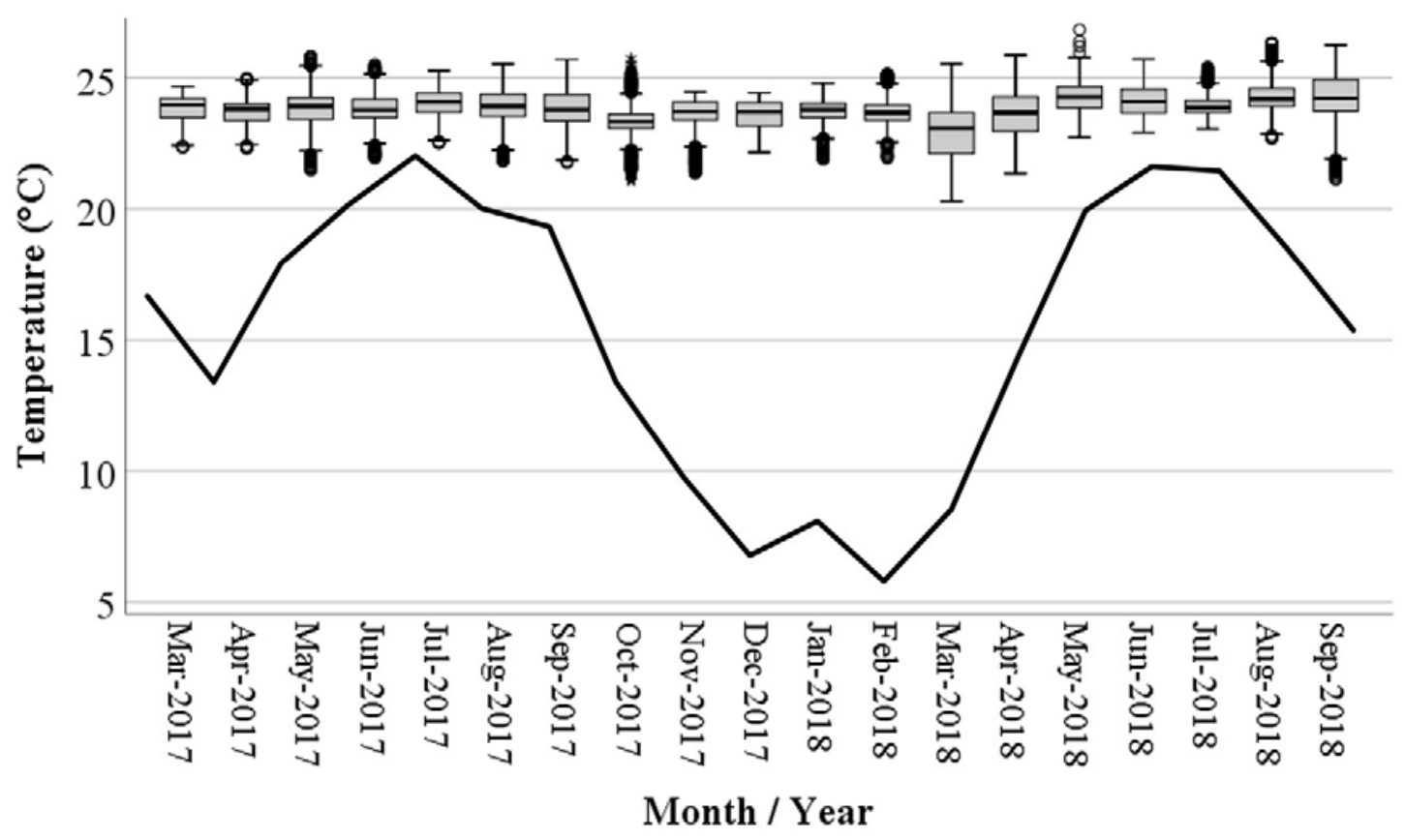

Figure 3 Boxplots of temperatures during working hours in the case-study working areas, with line showing monthly average outdoor temperatures during working hours.

The distinction between seasons is more apparent in Figure 4 where, although peak indoor temperatures were about the same, mean temperatures during working hours were around $0.5^{\circ} \mathrm{C}$ higher in the non-heating season.

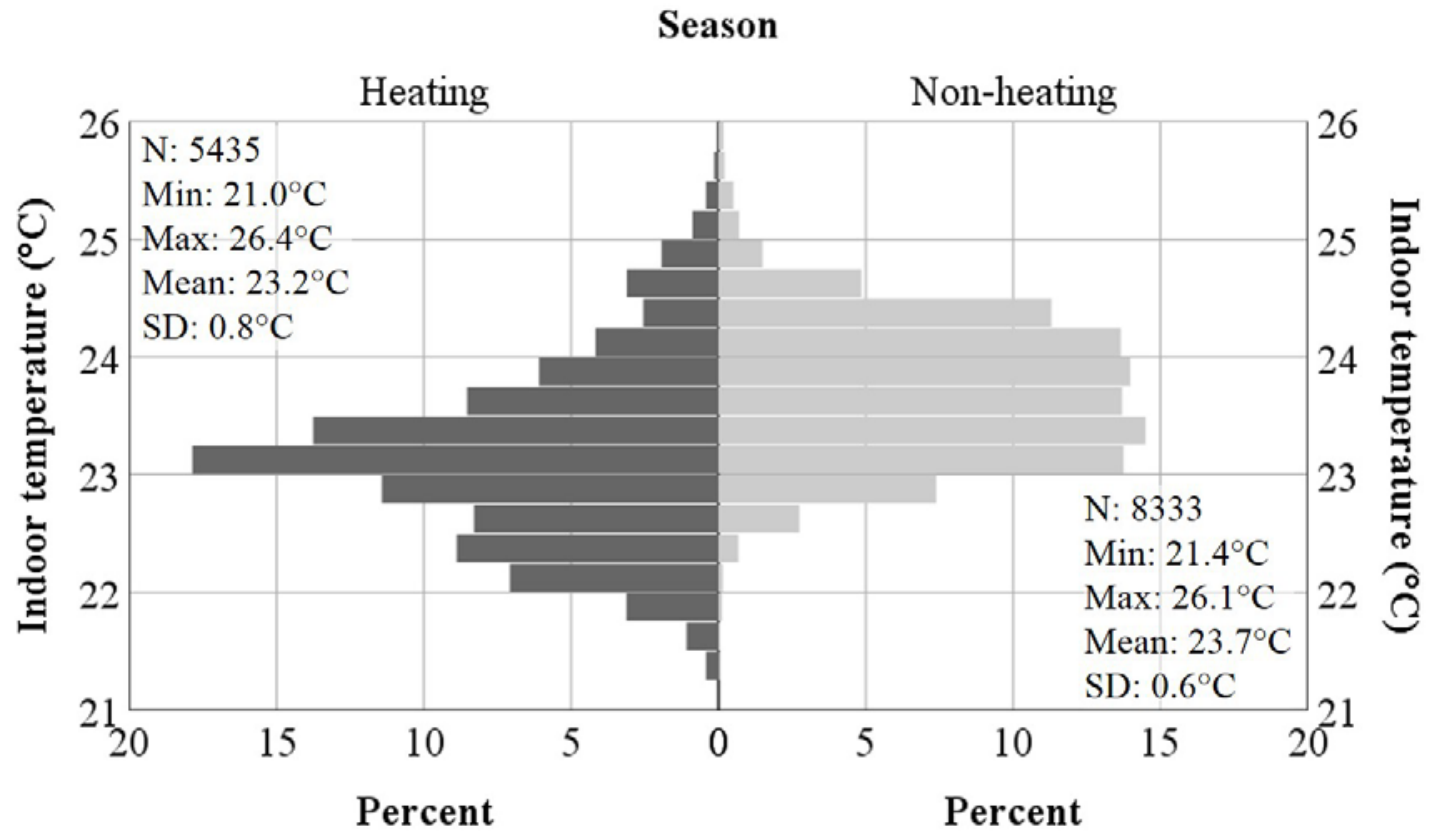

Figure 4 Population pyramid showing distribution of temperatures during working hours in the heating and non-heating seasons, with descriptive statistics also given.

The diurnal stability of the indoor temperatures is apparent in Figure 5, which shows the 
indoor and outdoor temperature profiles over a sample Monday-Friday week in the heating season $\left(5^{\text {th }}-9^{\text {th }}\right.$ February 2018$)$ and non-heating season $\left(24^{\text {th }}-28^{\text {th }}\right.$ July 2017$)$.

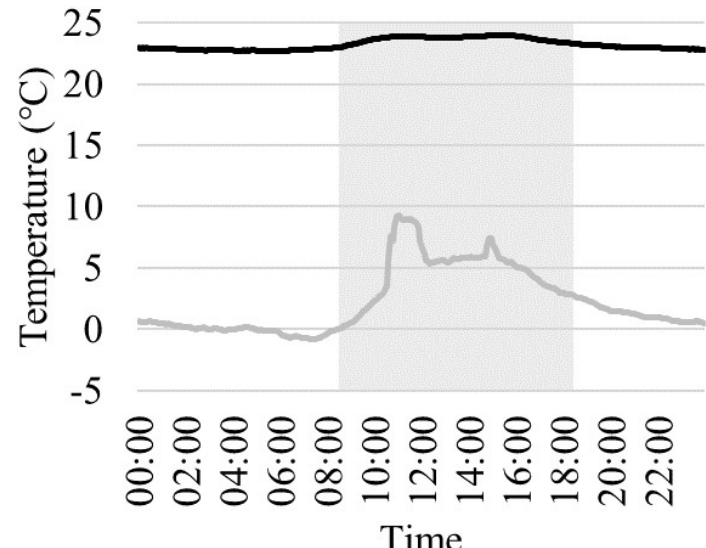

-Indoor - Outdoor

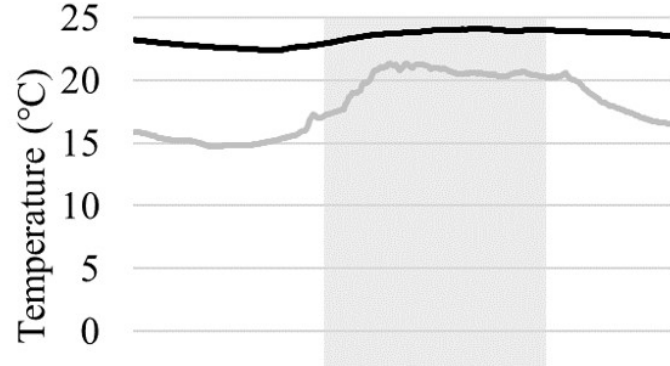

$-5$

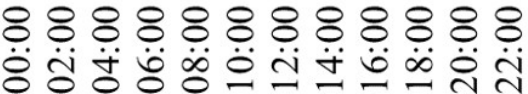

Time

-Indoor - Outdoor

Figure 5 Indoor and outdoor temperature profiles averaged over 5 working days: $5^{\text {th }}-9^{\text {th }}$ Feb 2018 (left); $24^{\text {th }}$ $28^{\text {th }}$ Jul 2017 (right). Shaded area represents occupied working hours.

In contrast to indoor temperature, indoor RH levels showed much more variation over the course of the monitored period. Figure 6 shows the boxplot of indoor RH during working hours by month, with the monthly average outdoor RH during working hours also shown. The recommended RH range in offices is 40-70\% (CIBSE 2015). During the heating seasons (March-April 2017 and October 2017-April 2018), indoor RH was below $40 \%$ for $66 \%$ of occupied hours, and below $30 \%$ for $25 \%$ of occupied hours. 


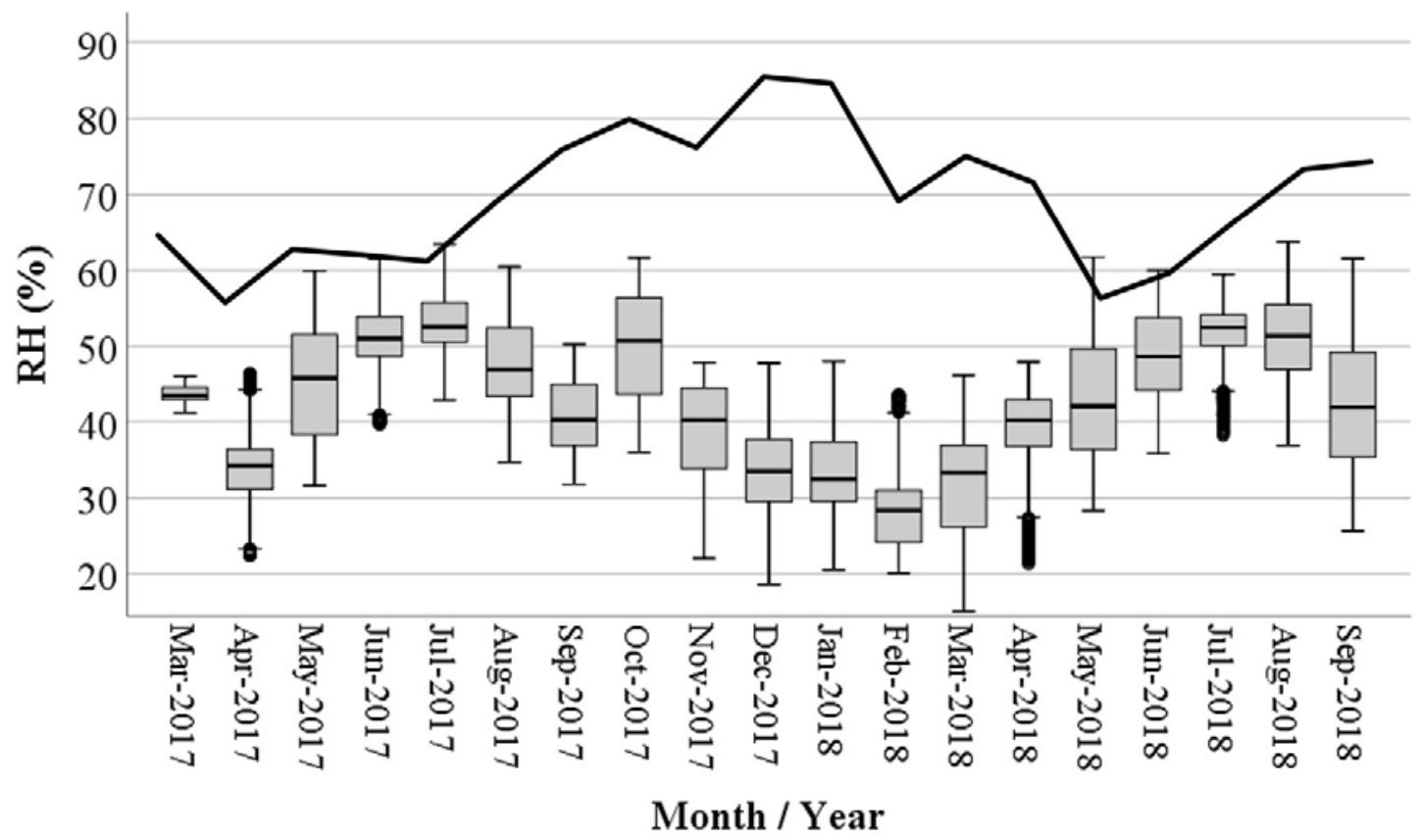

Figure 6 Boxplots of RH during working hours in the case-study working areas, with line showing monthly average outdoor RH during working hours.

In contrast, during the non-heating seasons (May-September 2017 and May-September 2018), when outdoor RH is generally lower than during the heating season, indoor RH was below $40 \%$ for only $19 \%$ of occupied hours and below $30 \%$ for less than $1 \%$ of occupied hours (Figure 7). 


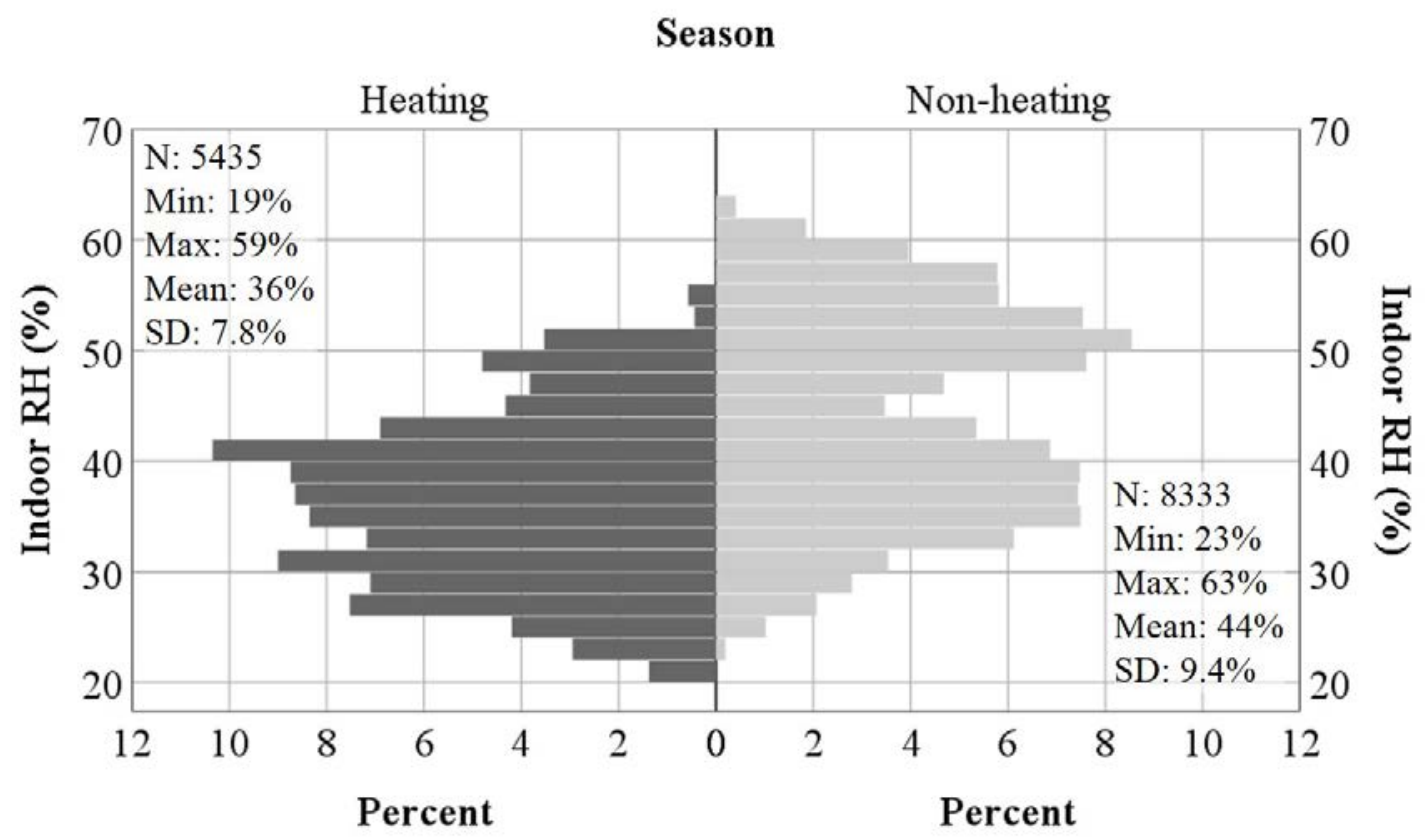

Figure 7 Population pyramid showing distribution of RH during working hours in the heating and nonheating seasons, with descriptive statistics also given.

The diurnal stability of indoor RH levels is apparent in Figure 8, which shows the indoor and outdoor temperature profiles over a sample Monday-Friday week in the heating season $\left(5^{\text {th }}-9^{\text {th }}\right.$ February 2018$)$ and non-heating season $\left(24^{\text {th }}-28^{\text {th }}\right.$ July 2017$)$.
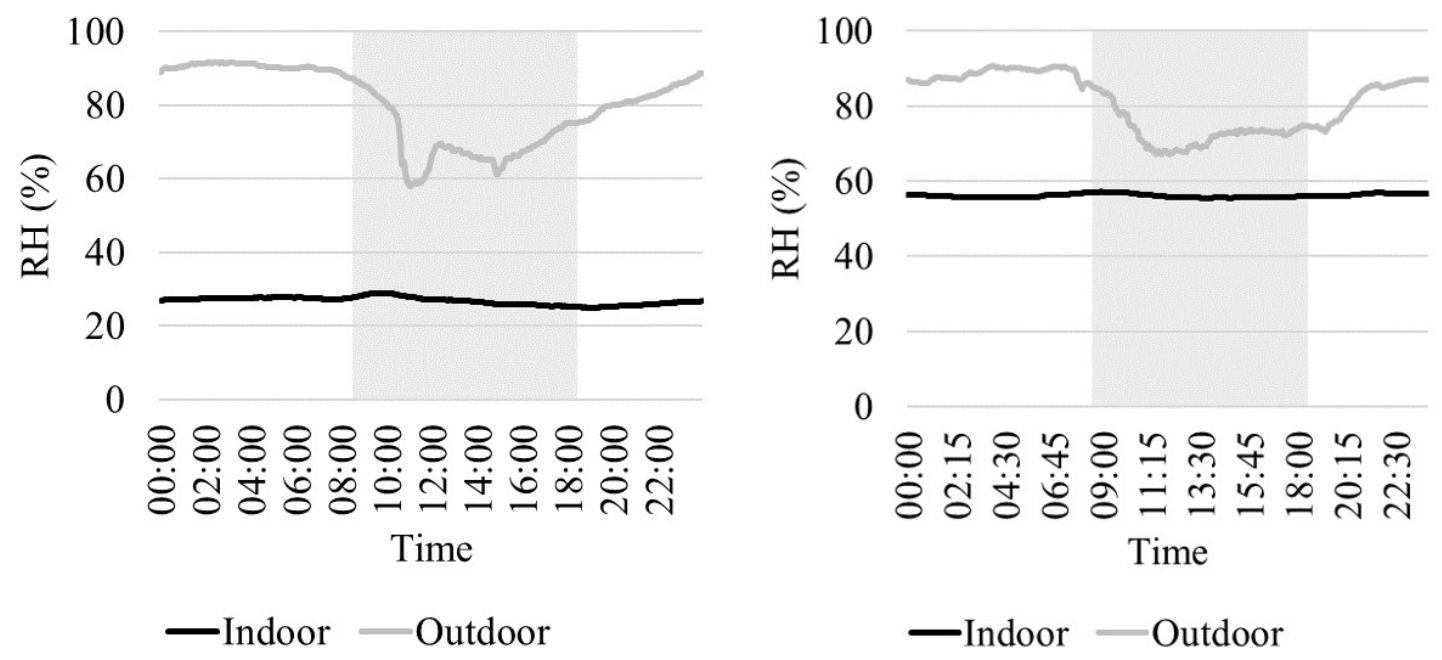

Figure 8 Indoor and outdoor RH profiles averaged over 5 working days: $5^{\text {th }}-9^{\text {th }}$ Feb 2018 (left); $24^{\text {th }}-28^{\text {th }}$ Jul 2017 (right). Shaded area represents occupied working hours.

Although the range of outdoor temperatures was much greater than indoor temperatures, both daily and seasonally, the correlation between the two was moderately strong (Pearson correlations $\mathrm{p}=0.50$ and 0.48 during the heating and non-heating seasons 
respectively, both significant at the 0.01 level) (Figure 9). The correlation between outdoor and indoor RH was very weak during the heating season (Pearson correlation $\mathrm{p}$ $=0.10)$ but moderate during the non-heating season $(p=0.54)$, both statistically significant at the 0.01 level.
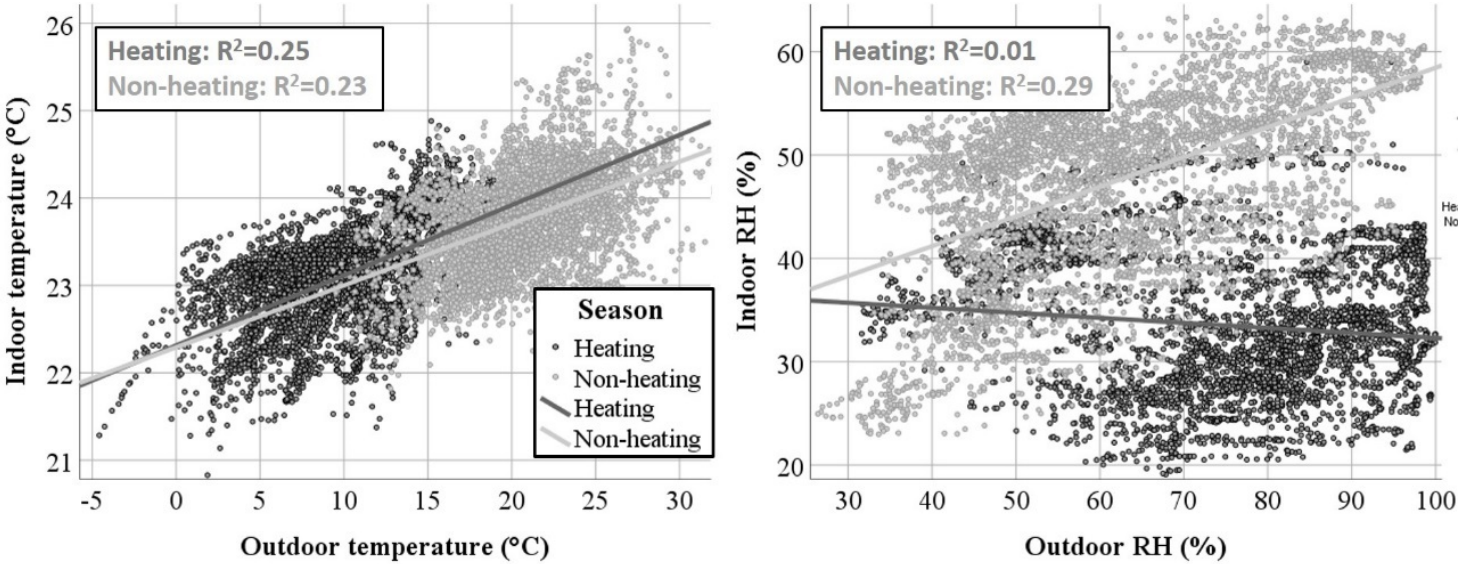

Figure 9 Scatterplots of concurrent outdoor and indoor temperatures (left) and outdoor and indoor RH (right), showing linear trend lines for both the heating and non-heating seasons.

$\mathrm{CO}_{2}$ concentration varied throughout the year but remained below $1000 \mathrm{ppm}$

(recommended limit in UK offices - CIBSE, 2015) for $92 \%$ and $99 \%$ of occupied hours during the heating and non-heating seasons respectively (Figure 10).

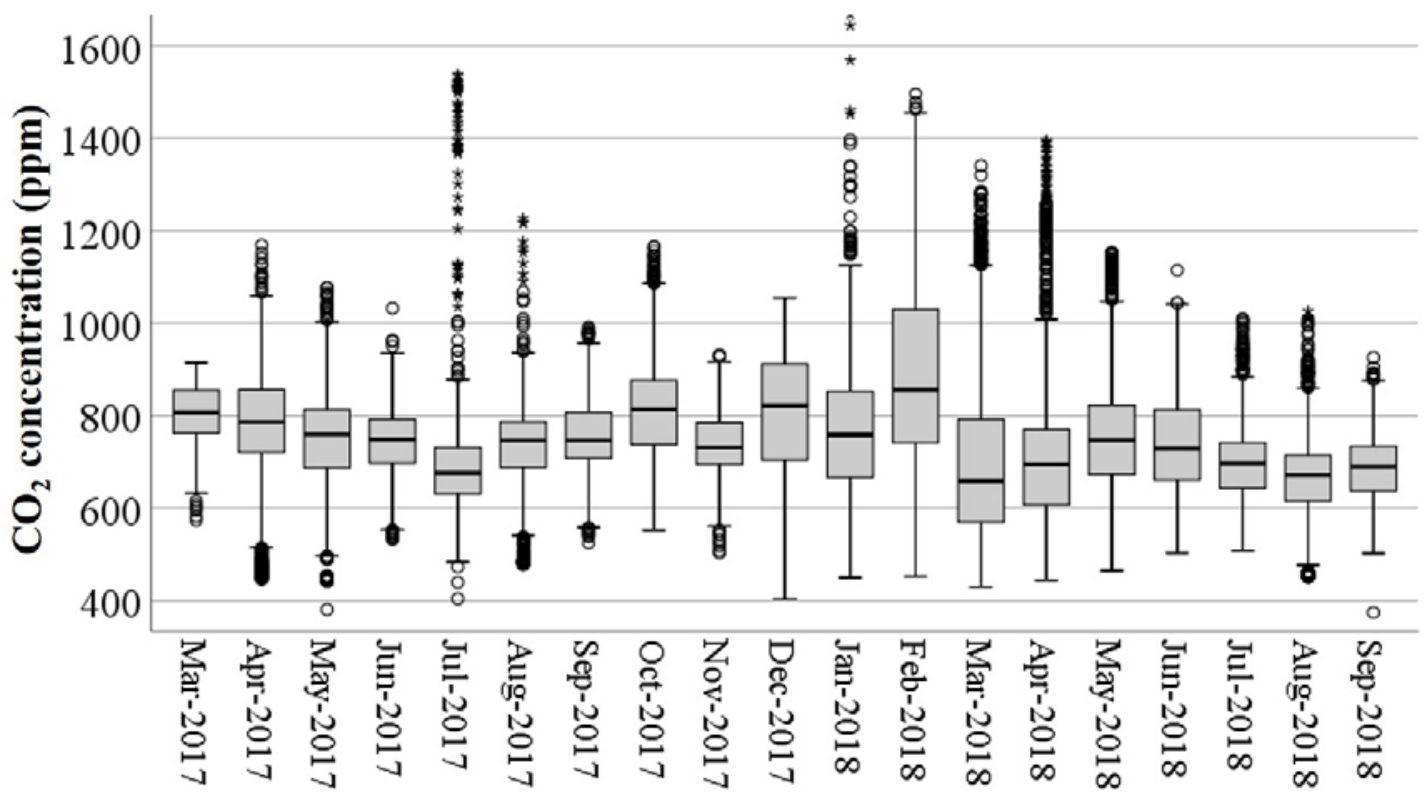

\section{Month / Year}

Figure 10 Boxplots of $\mathrm{CO}_{2}$ concentration during working hours in the case-study working areas. 
Spikes in $\mathrm{CO}_{2}$ concentration were rare and brief. Although peak $\mathrm{CO}_{2}$ concentrations were greater during the heating season, the mean $\mathrm{CO}_{2}$ concentration was more than 60 ppm greater during the non-heating season (Figure 11).

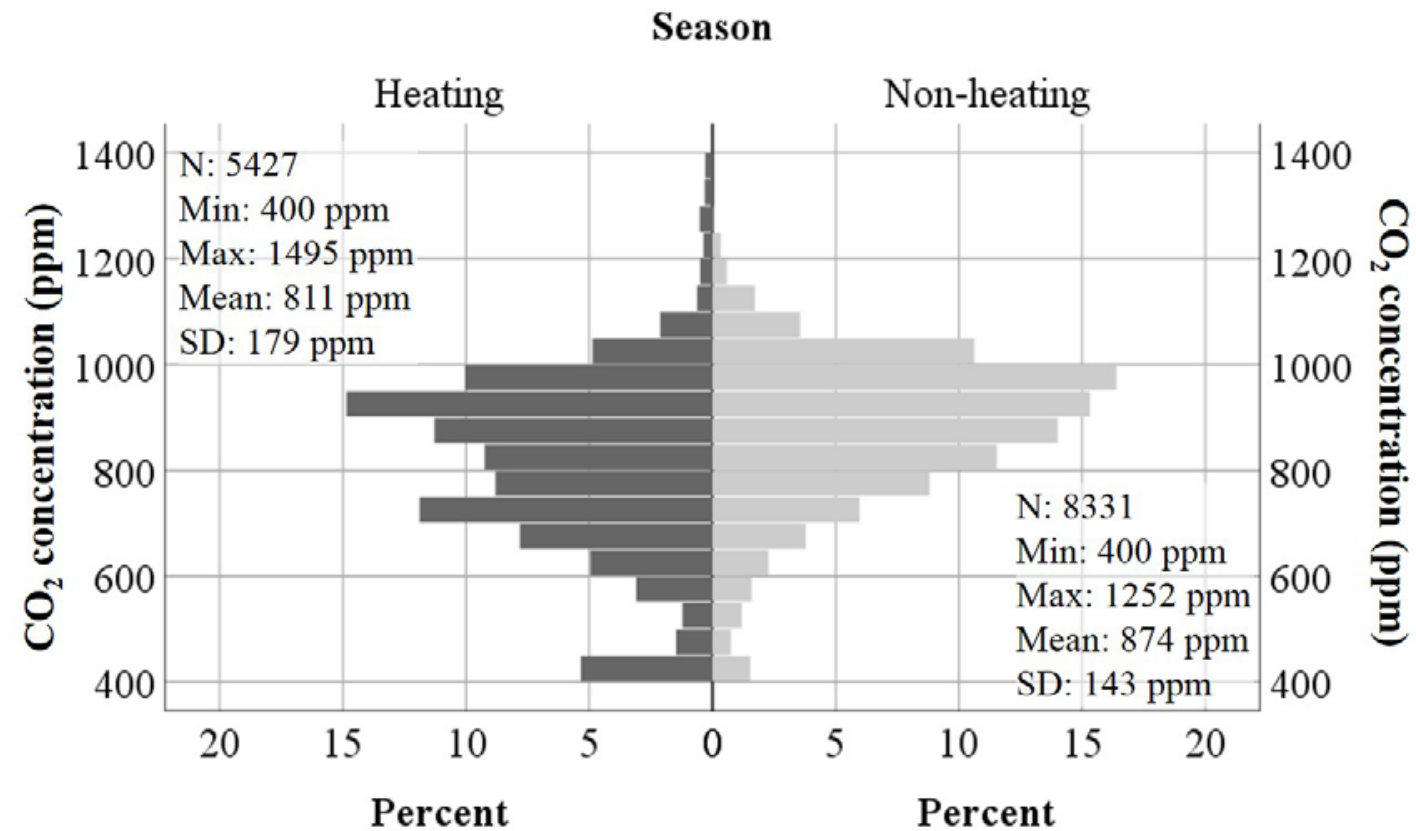

Figure 11 Population pyramid showing distribution of $\mathrm{CO}_{2}$ concentrations during working hours in the heating and non-heating seasons, with descriptive statistics also given.

In contrast to the typical diurnal temperature and $\mathrm{RH}$ profiles, $\mathrm{CO}_{2}$ levels varied significantly (Figure 12). Over the course of a typical weekday, $\mathrm{CO}_{2}$ concentrations tended to rise steeply at the start of the working day, increasing from ambient levels in the 400-500 ppm range until late morning (11:00 - 12:00) when they would plateau and remain stable until the end of the working day when they would decrease back to ambient levels in the evening. The spike in $\mathrm{CO}_{2}$ concentration seen in the heating season profile (Figure 12, left) was an anomaly caused by particularly high readings on the morning of $5^{\text {th }}$ February 2018. 


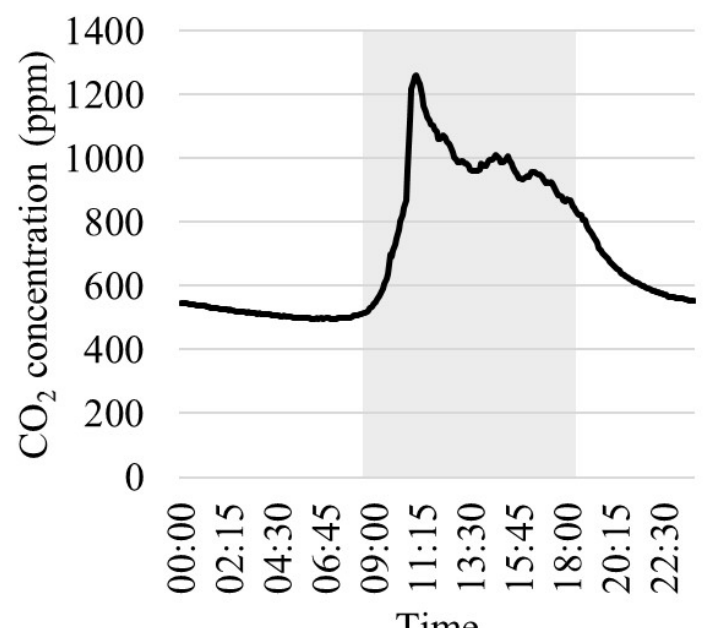

Time

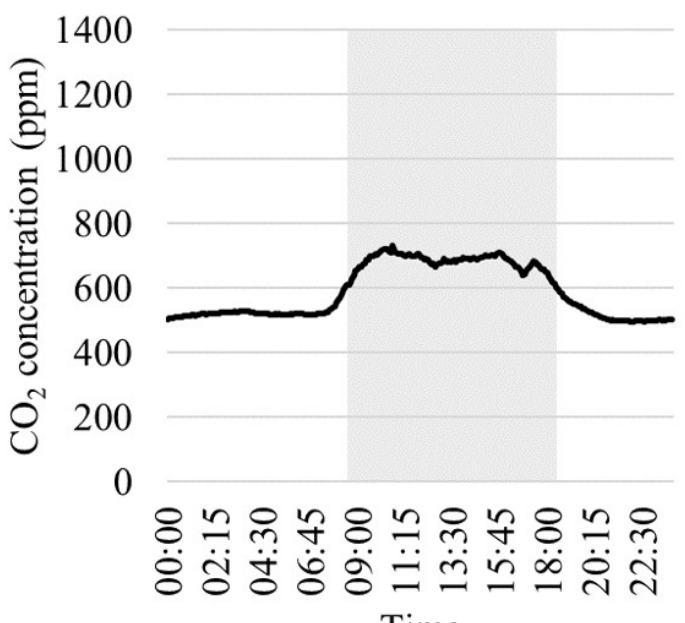

Time

Figure $12 \mathrm{CO}_{2}$ concentration profiles averaged over 5 working days: $5^{\text {th }}-9^{\text {th }}$ Feb 2018 (left); $2^{\text {th }}-28^{\text {th }}$ Jul 2017 (right). Shaded area represents occupied working hours.

\section{Baseline period}

\section{Perceived productivity and indoor environment}

The BUS survey (n: 69) provided a transverse view of occupant perception of their working environment during summer and winter and self-reported change in productivity. Paper copies of the survey were handed out to all occupants of the case study working areas between 11:00 and 12:00 and collected between 16:00 and 17:00 the same day. The response rate was approximately $47 \%$. Respondents were asked questions relating to their perception of the building in terms of space, comfort and amenities, their perception of temperatures and air in the summer and winter, and their perception of how the building affects their health and productivity. Specifically, occupants were asked, 'Please estimate how you think your productivity at work is decreased or increased by the environmental conditions in the building?', with responses on a scale from ' $-40 \%$ or less' to ' $+40 \%$ or more' in $10 \%$ increments. Overall, occupants estimated that their productivity decreased by a median average of 
$10 \%$ due to the indoor environmental conditions $($ mean $=6.1 \%$ decrease, mode $=10 \%$ decrease). Interestingly when occupants perceived the environment to be unfavourable (e.g. thermally uncomfortable, stuffy air or unsatisfactory overall), their perceived productivity decreased (Figure 13). Notably, other indoor environmental parameters (such as whether the temperature was stable or varied, whether the air was still or draughty or whether the air was dry or humid) showed no statistically significant relationship to occupants' perception of their change in productivity. 


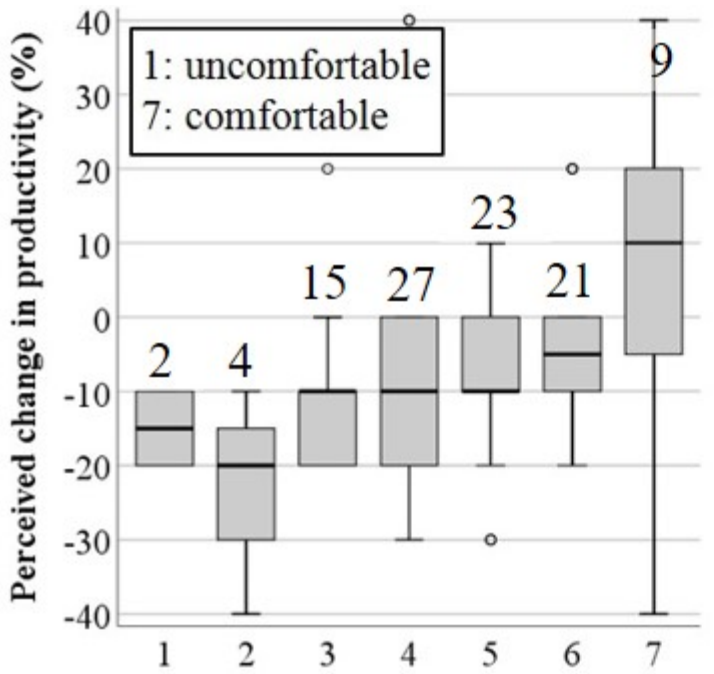

Temperature in winter: Overall

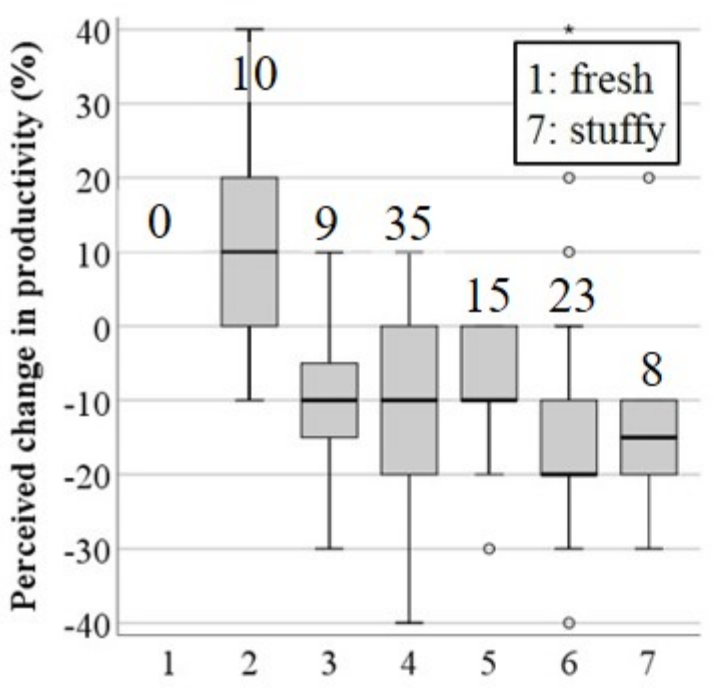

Air in winter: Fresh/Stuffy

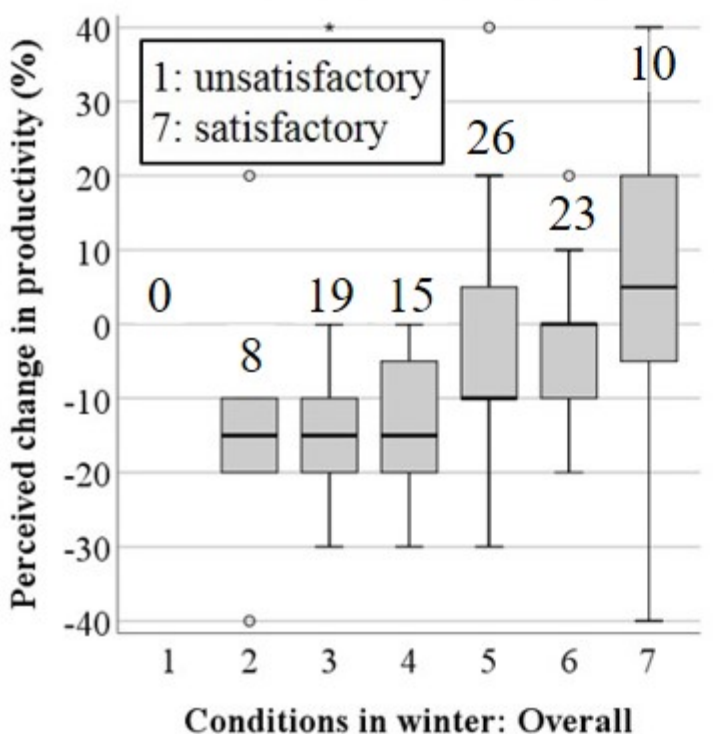

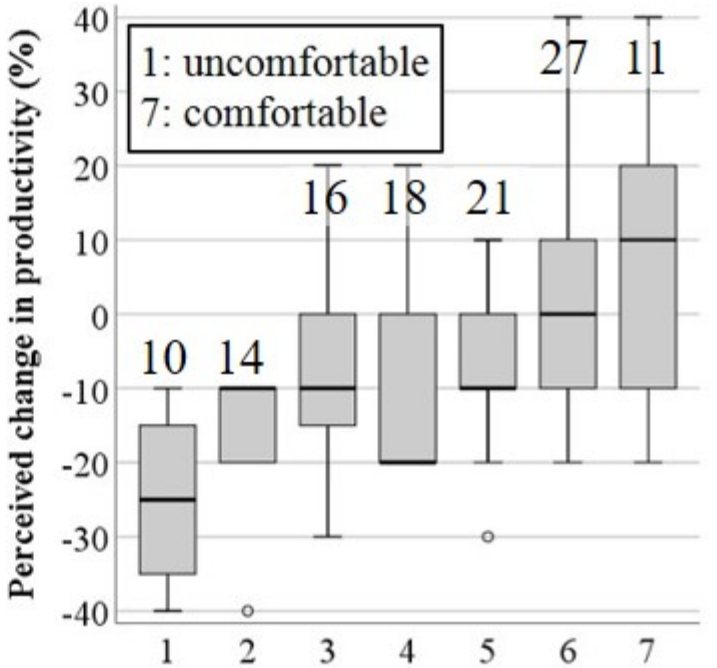

Temperature in summer: Overall

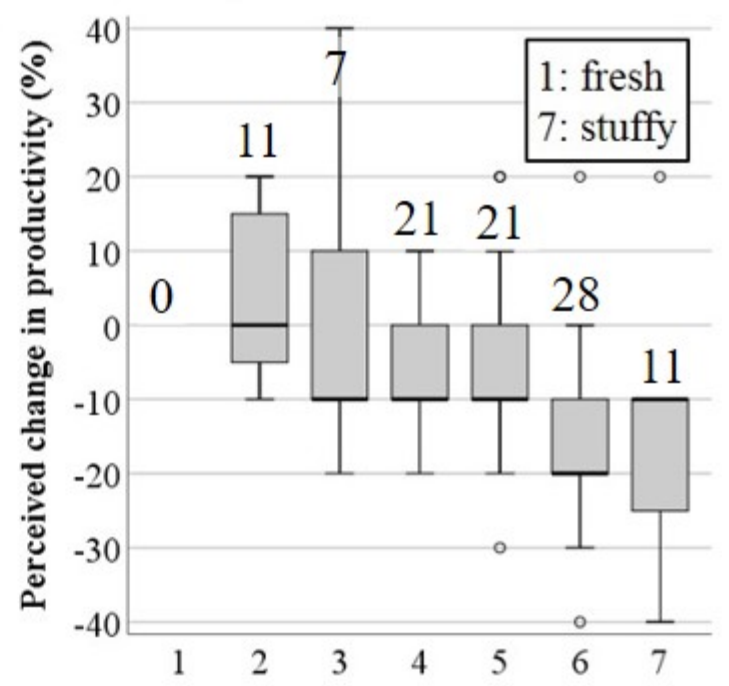

Air in summer: Fresh/Stuffy

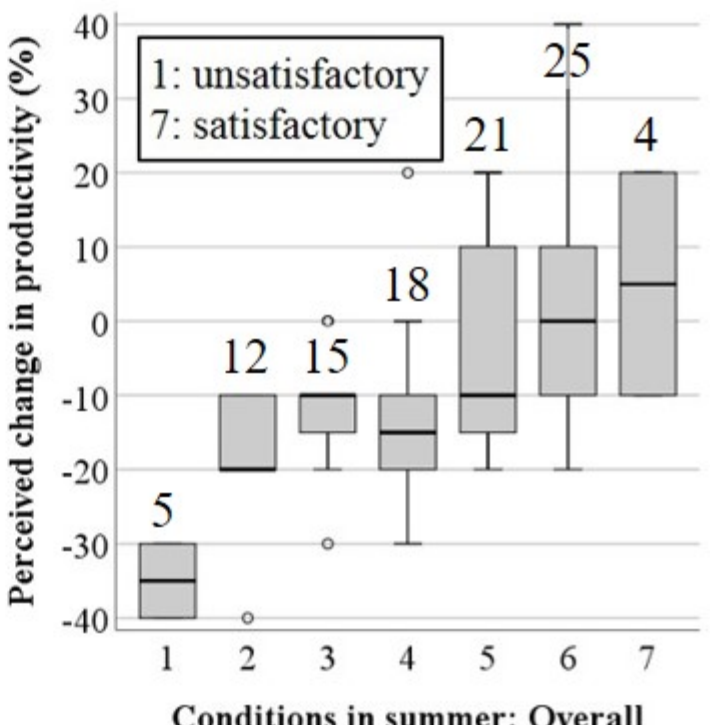

Conditions in summer: Overall 
Figure 13 Boxplots of selected BUS questionnaire responses plotted against perceived change in productivity (with distribution of responses shown by percentage).

The longitudinal survey was conducted from 11 to 24 May 2017 and from 11 to 17 July 2017, three times a day for fifteen days in total. A total of 950 responses were received, with approximately 100 of the 160 or so individuals participating in at least one survey. The mean number of responses from those who did respond was 6.6, with a maximum of 37 responses from one individual. The respondents were a self-selecting group as this allowed the maximum potential responses with the minimum potential disruption to their normal workload: respondents were able to respond whenever they wanted within a 2-3 hour window, but were under no obligation to do so as it was important at this stage and all stages of the project to keep the occupants 'on side'. A link to the questionnaire was sent via e-mail to the occupants three times a day (mid-morning, early afternoon and late afternoon). The responses were time stamped and respondents also indicated their location so concurrent indoor environmental measures could be identified. Respondents were asked to indicate their perceived thermal comfort (on a 7point scale from 'much too cool' to 'much too warm'), their thermal preference (on a 5point scale from ('much cooler' to 'much warmer'), perceived air quality (on a 7-point scale from 'fresh' to 'stuffy') and overall comfort (on a 7-point scale from 'uncomfortable' to 'comfortable'). The responses to each of these questions were close to normally distributed, with air quality skewed slightly toward stuffy rather than fresh and overall comfort skewed slightly towards comfortable rather than uncomfortable. Occupants were also asked about their productivity ('At present, please estimate how you think your productivity has decreased or increase by the environmental conditions in the building'). Responses were on a scale from ' $-20 \%$ or less' to ' $+20 \%$ or more' in $5 \%$ increments. 
Plotting the occupants' responses to their perceptions of the environment against their perceived changes in productivity showed significant interrelationships (Figure 14). Around $73 \%$ of responses were in the thermally comfortable middle of the scale ('comfortably cool', 'comfortable...' and 'comfortably warm'), where occupants perceived their productivity to be neutral. When occupants felt cool ( $6 \%$ of responses) or warm ( $21 \%$ of responses), they perceived their productivity to be decreased (more so at the warm end of the scale than at the cool end). Notably, occupants perceived their productivity to be more positively affected when they were comfortably cool than neutrally comfortable or comfortably warm. (Within this and subsequent boxplots, where there is a line rather than a box, this indicates that the upper quartile, median and lower quartiles were all the same).

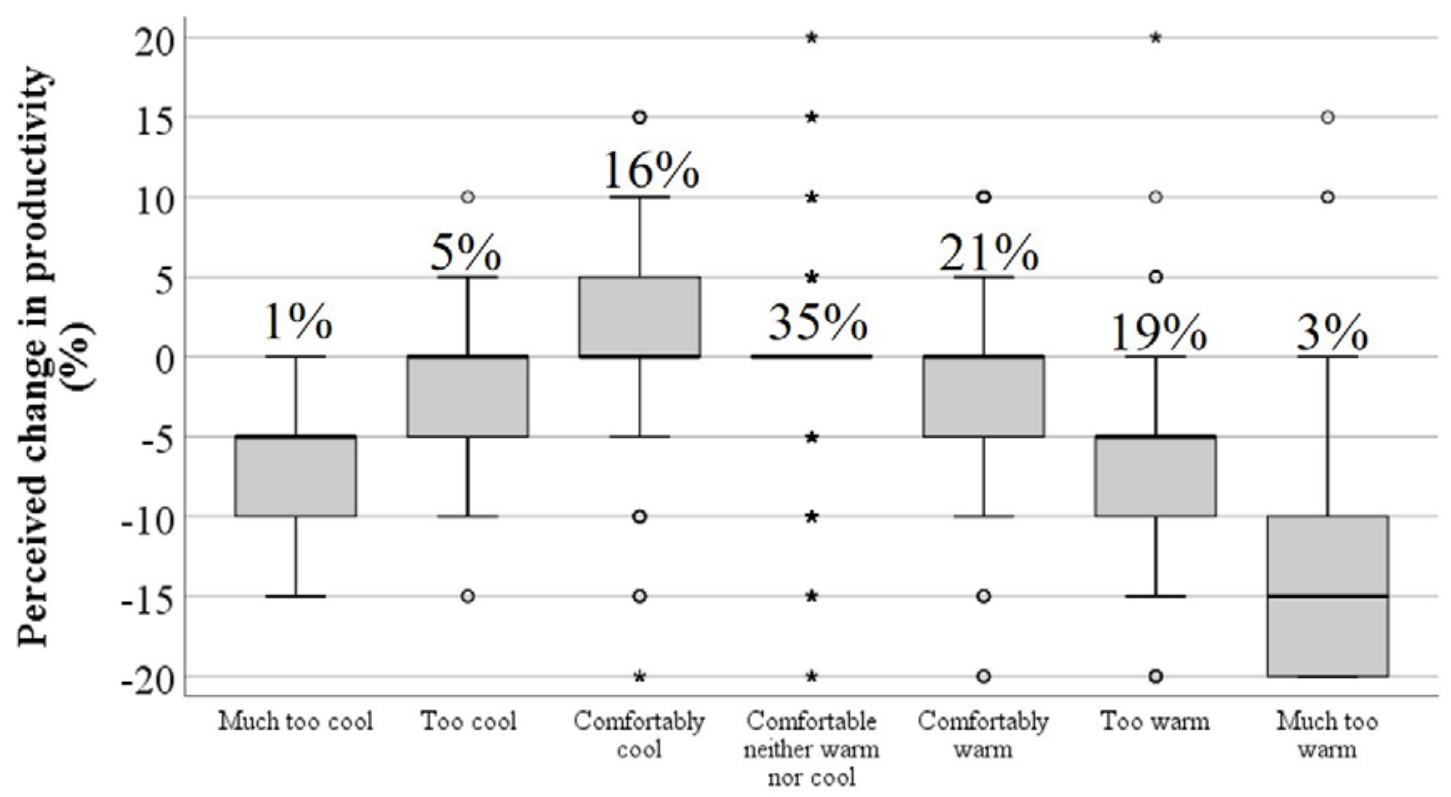

Thermal sensation votes

Figure 14 Boxplot of thermal sensation votes vs. perceived change in productivity votes $(n=953)$.

By comparison, plotting thermal sensation votes against concurrent indoor temperatures showed very little variation in the distribution of temperatures except towards the 'warm' end of the scale (Figure 15). Temperatures in the $23.5-24.5^{\circ} \mathrm{C}$ range were 
perceived by some to be 'much too cool' and others to be 'much too warm' (and everything in between), indicating how subjective thermal comfort was, particularly in such a tightly controlled environment.

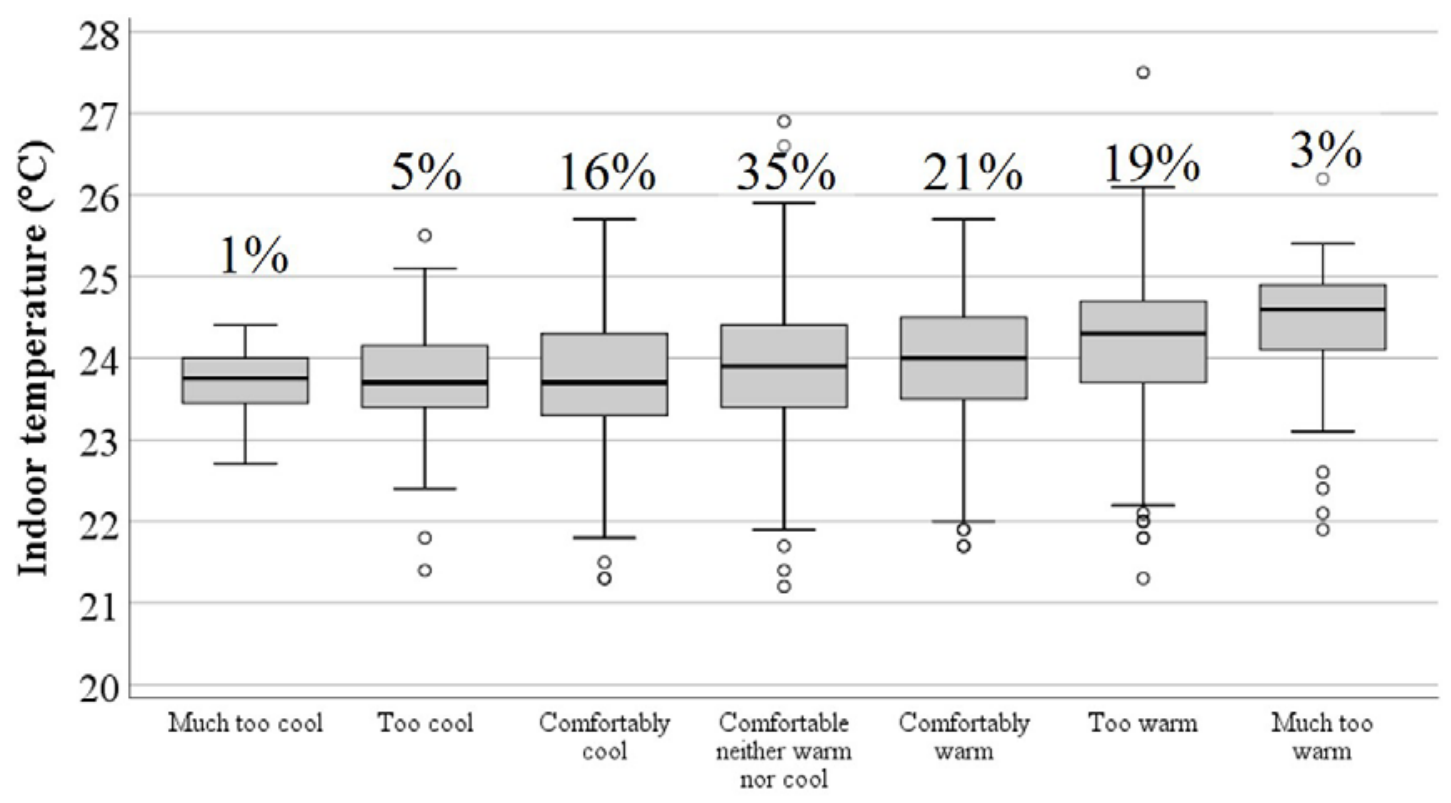

Thermal sensation votes

Figure 15 Boxplot of thermal sensation votes vs. concurrent indoor temperatures $(n=953)$.

Thermal preference votes similarly showed that when respondents wanted to be warmer or cooler, they perceived their productivity to be negatively affected (Figure 16). Close to $49 \%$ of responses indicated they were content with the thermal conditions ("no change'), with $41 \%$ wanting to be cooler and only $10 \%$ wanting to be warmer. 


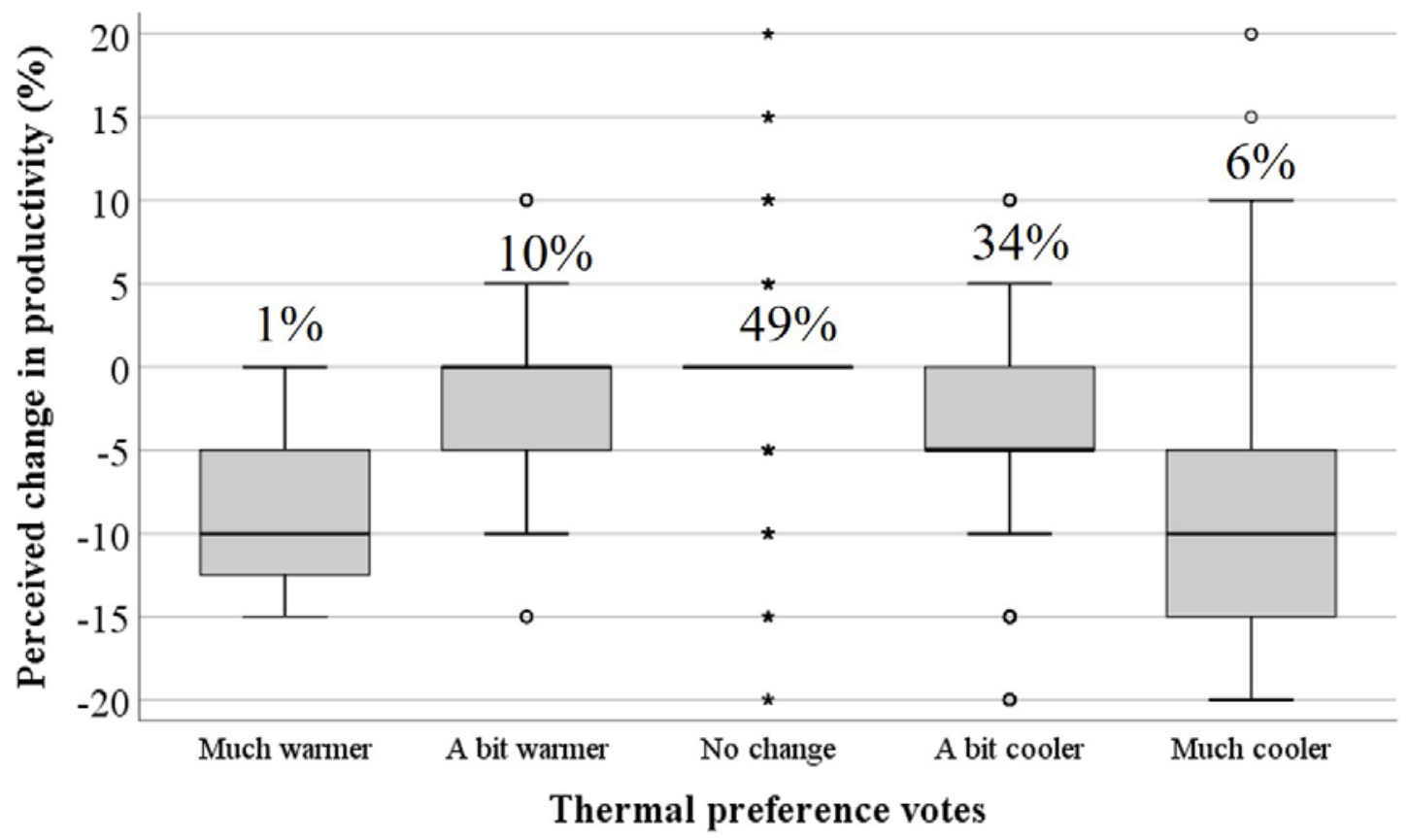

Figure 16 Boxplot of thermal preference votes vs. perceived change in productivity $(n=953)$.

The relationship between perceived air quality and perceived change in productivity was weaker by comparison, but still showed that as occupants perceived their environment becoming more stuffy, they also perceived their productivity deteriorating (Figure 17). Notably, as with thermal sensation and measured temperature, there was no significant correlation found between perceived air quality votes and any measures of the indoor environment (temperature, $\mathrm{RH}$ or $\mathrm{CO}_{2}$ concentration). 


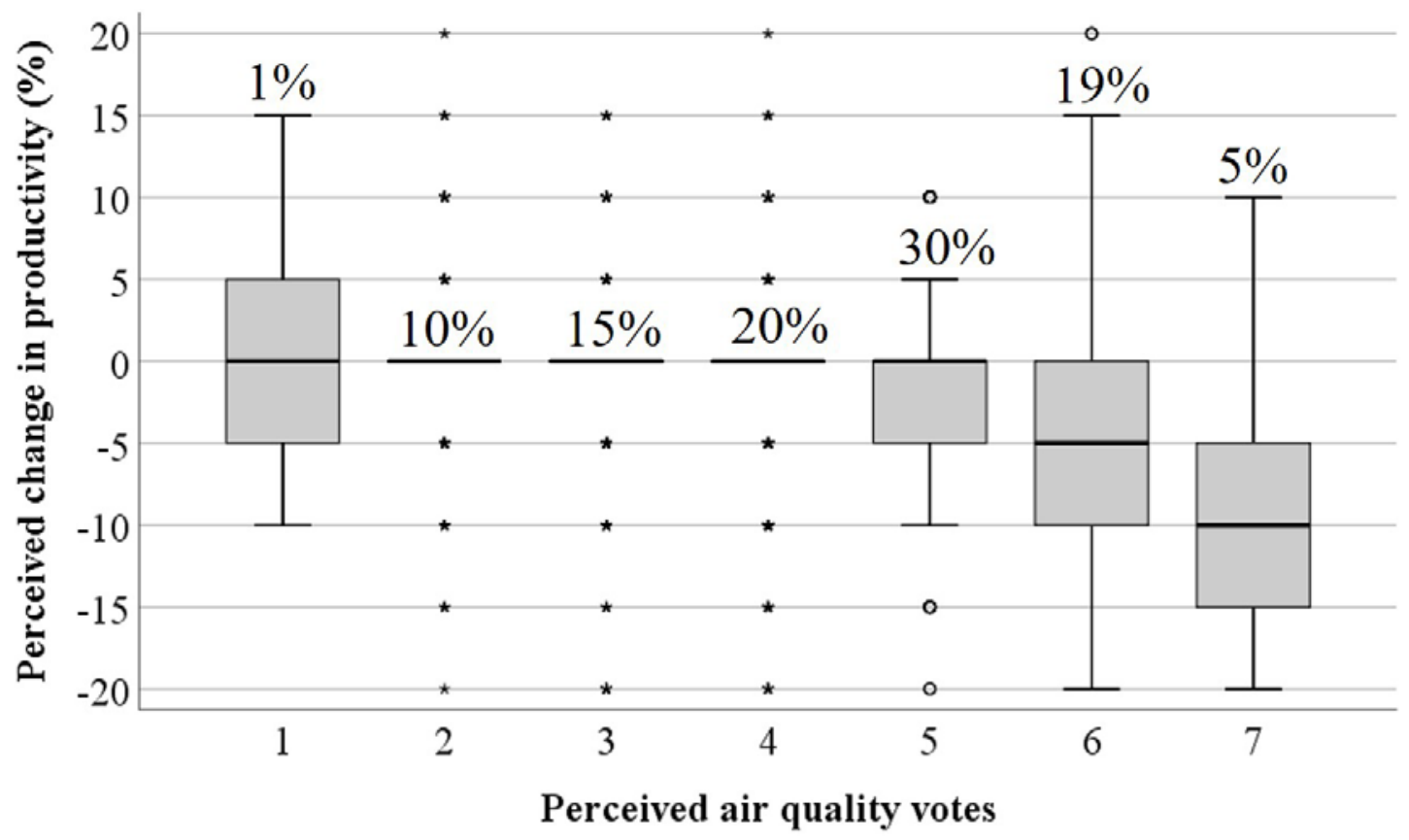

Figure 17 Boxplot of perceived air quality votes vs. perceived change in productivity (n=953): 1 = 'fresh, $7=$ 'stuffy'.

Plotting perceived overall comfort votes against perceived change in productivity had similar results: when occupants felt comfortable overall, they perceived their productivity to be neutral or slightly improved, whereas the more uncomfortable they felt overall, the more negatively affected they perceived their productivity to be (Figure 18). 


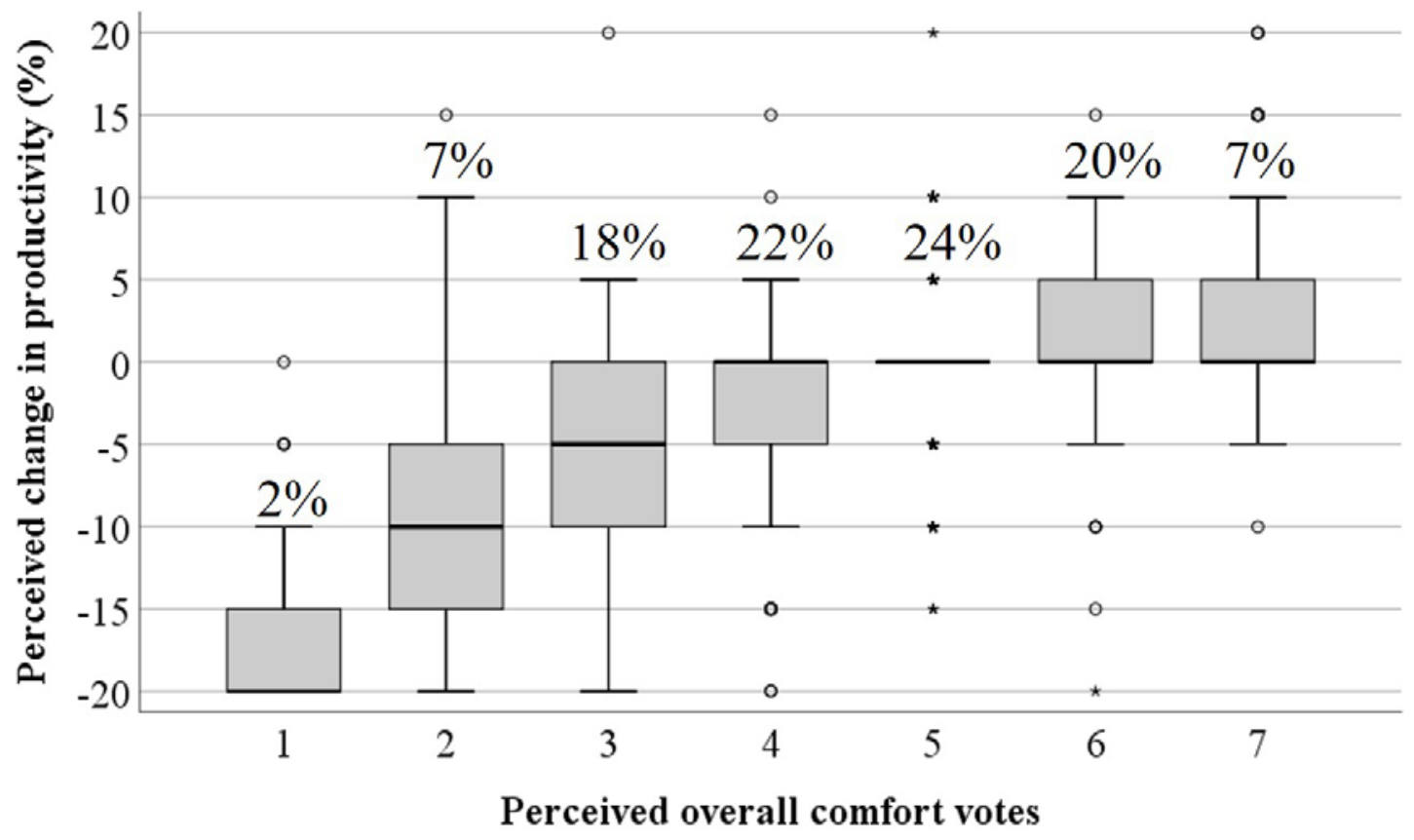

Figure 18 Boxplot of perceived overall comfort vs. perceived change in productivity ( $n=953): 1=$ uncomfortable, 7 = comfortable.

The relationship between how occupants perceived their environmental conditions and how they perceived their productivity to be affected was evident. However, plotting measured indoor environmental conditions against perceived change in productivity produced no statistically significant relationships, indicating the subjective nature of both perceptions of the indoor environment and perceptions of how this environment contributes to changes in productivity.

\section{Measured productivity and indoor environment}

Performance tasks were conducted from 5 to 9 June and from 24 to 28 July 2017 (n: 285). As with the surveys, tasks were time stamped so concurrent indoor conditions could be cross-related. Links to the online tasks were sent via e-mail twice a day (midmorning and mid-afternoon. The Stroop test was the most popular test type, receiving $53 \%$ of responses, followed by the proofreading test (27\%) and numerical (20\%).

Performance tasks were given to the same cohort of individuals as was given the BUS 
and longitudinal surveys, and there was significant overlap in the individuals who chose to respond.

The range of indoor temperatures concurrent with task completion was small (predominantly $22-25^{\circ} \mathrm{C}$ ), therefore making it difficult to identify significant correlations. Although a (weak) negative correlation was found (Pearson correlation $\mathrm{r}=$ $-0.07)$, indicating that as indoor temperature increased, the proportion of correct answers decreased, this was not statistically significant at the 0.05 level (Figure 19).

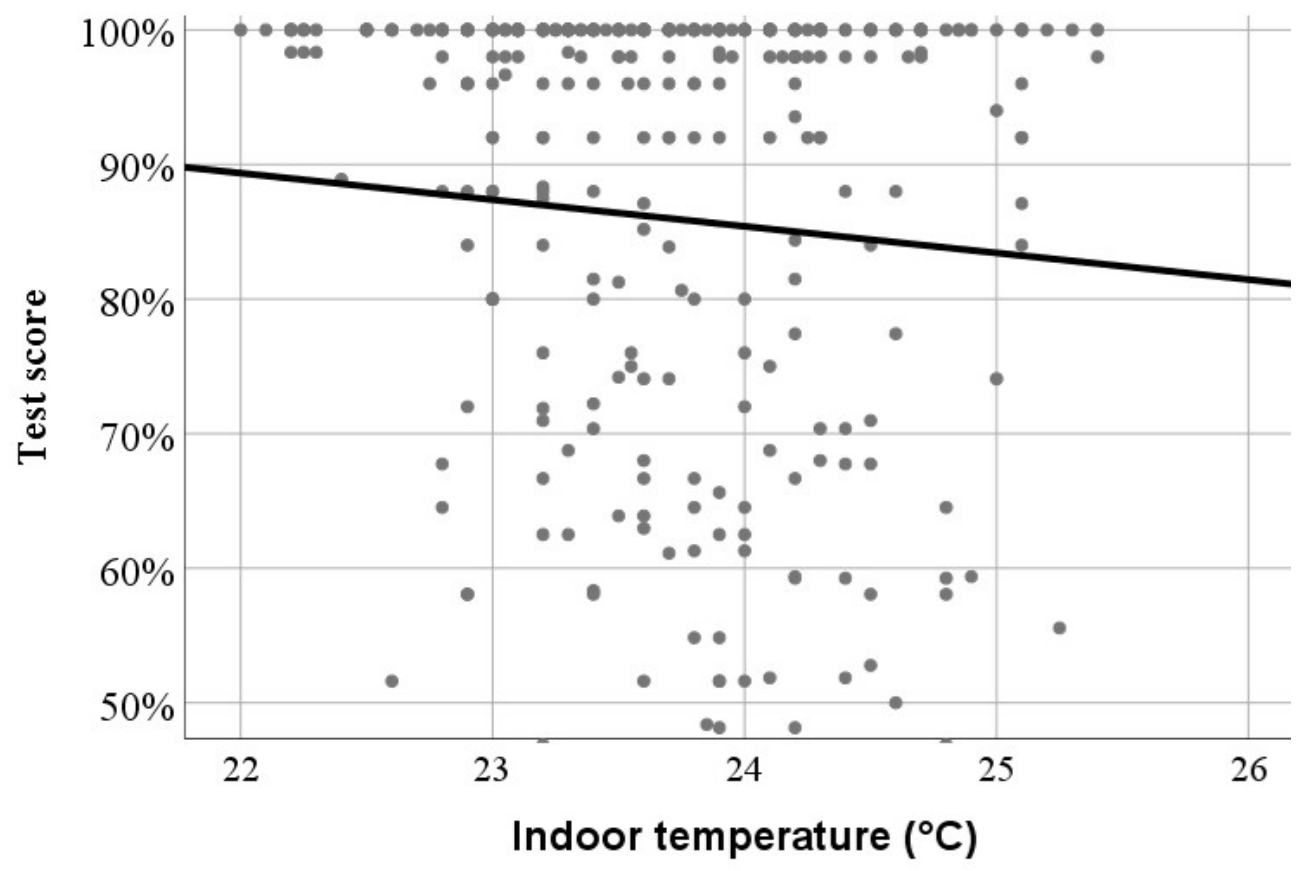

Figure 19 Indoor temperature vs. test score.

To investigate if there were any statistically significant correlations between the measured indoor environment (temperature, $\mathrm{RH}$ or $\mathrm{CO}_{2}$ concentration) and task results (test score or test duration), interventions were conducted. 


\section{Intervention period}

Based on the findings from the baseline period, the BMS was used to control the indoor environment over two four-week periods:

- During the first intervention period (23 October to 17 November 2017), the temperature was more tightly controlled to set-points of $21.5^{\circ} \mathrm{C}, 22.0^{\circ} \mathrm{C}, 22.5^{\circ} \mathrm{C}$ and $23.0^{\circ} \mathrm{C}$ (one set-point per week).

- During the second intervention period (15 May to 12 June 2018), $\mathrm{CO}_{2}$ concentrations were more tightly controlled to set-points of $1000 \mathrm{ppm}, 1200$ ppm and 1500 ppm (one set-point per week following a week of ambient levels). Maintaining these set-points proved challenging for the BMS, and as an indication of how intolerant occupants could be to perceived uncomfortable conditions, the temperature set-point of $21.5^{\circ} \mathrm{C}$ had to be abandoned mid-week due to the facilities management team receiving complaints from occupants that they were too cold. As there was significant overlap in measured temperatures and $\mathrm{CO}_{2}$ concentrations within the intervention weeks, the results of the surveys and tasks have been considered as a whole rather than by set-point weeks.

During both periods, online surveys and performance tasks were repeated and time stamped, with surveys being conducted three times a day (mid-morning, early afternoon and late afternoon) on Mondays and Tuesdays and tasks twice a day (midmorning and mid-afternoon) on Wednesdays, Thursdays and Fridays.

\section{Perceived productivity and indoor environment}

The distribution of responses to thermal comfort votes was shifted mainly due to the temperature set-points during the first intervention period creating a cooler environment 
than experienced during the baseline period. Around $70 \%$ of responses were in the 'comfortably cool'/ 'comfortable' / 'comfortably warm' range, with $16 \%$ at the warm

end of the scale and $14 \%$ at the cool end. $45 \%$ of thermal preference votes were for "no change', with $30 \%$ wanting to be cooler and $25 \%$ wanting to be warmer. Plotting these results as boxplots against perceived change in productivity produced very similar outputs to the baseline. The distribution of perceived air quality votes and overall comfort votes were similar during both intervention periods to the baseline period, and again, the boxplots against perceived change in productivity produced very similar outputs to the baseline. These results served to emphasise the strong relationship between occupant perception of their environment and their perception of how this affects their productivity.

\section{Measured productivity and indoor environment}

As with the baseline, indoor temperatures concurrent with task completion covered a narrow range $\left(21-25^{\circ} \mathrm{C}\right)$, although the temperature intervention provided a more even spread of temperatures within this. The correlations between indoor temperatures and both test scores and test durations were very weak and not significant at the $p=0.05$ level. Similarly, there were no statistically significant correlations between RH and either test score or test duration, despite RH levels being below the recommended $40 \%$ for $39 \%$ of tasks completed.

Allowing $\mathrm{CO}_{2}$ concentrations to rise higher than occupants were used to during the second intervention period provided more test results conduced at the higher end of the $\mathrm{CO}_{2}$ range than in the baseline. Splitting the test scores and test durations between those conducted below 800 ppm and those conducted above 800 ppm (Figure 20) showed that for the proofreading tests, the median score was $94 \%$ for those conducted below 800 ppm, compared to $79 \%$ for tests conducted above 800 ppm. For proofreading 
tests, the median time to complete the test (test duration) was 5 minutes for those conducted below $800 \mathrm{ppm}$, compared to 6 minutes for those conducted above $800 \mathrm{ppm}$. It is notable that this $800 \mathrm{ppm}$ is the limit recommended by the WELL Building Standard (Delos Living 2016).
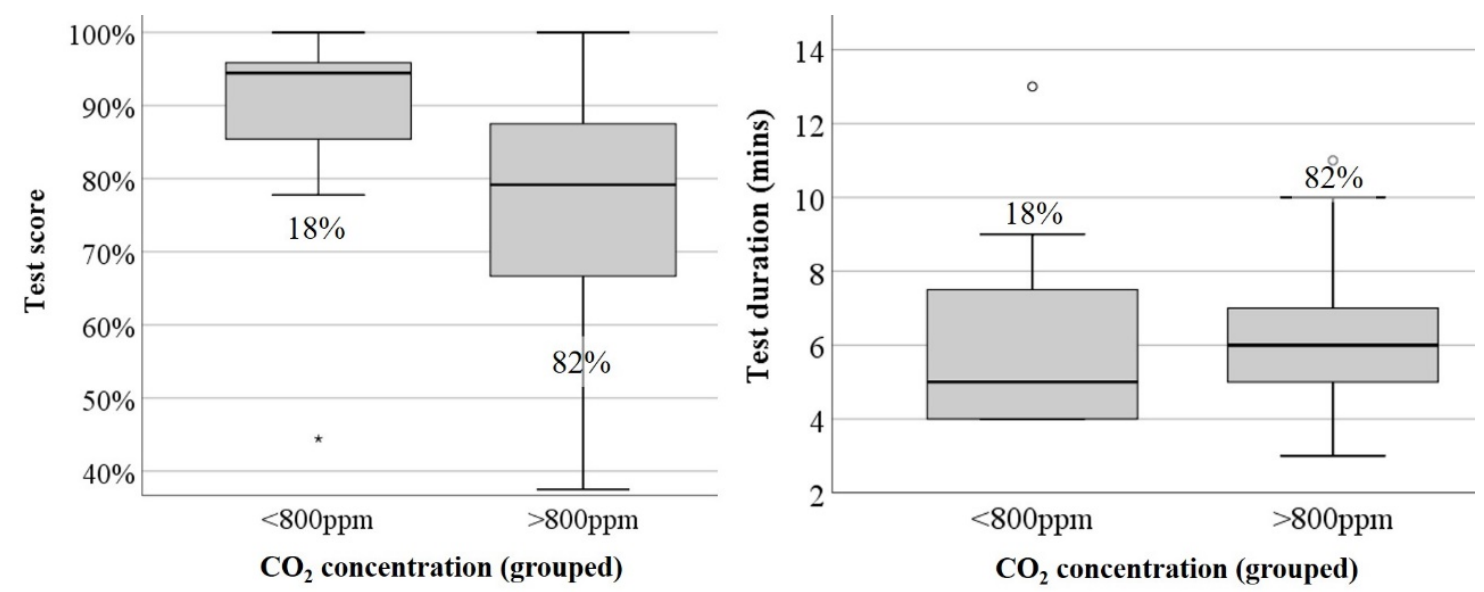

Figure 20 Boxplots of $\mathrm{CO}_{2}$ concentration against test score (left) and test duration (right) for the proofreading tests during the intervention periods.

It is evident from these results that temperatures and RH levels within the ranges experienced by the occupants were not extreme enough to show any negative impact on the performance tasks used in this study. However, when $\mathrm{CO}_{2}$ concentrations exceeded $800 \mathrm{ppm}$ there was a significant detrimental effect on both the test scores and durations for the proofreading tests.

\section{Participant response rates}

It is worth commenting on the participant engagement in both the surveys and performance tasks. Measuring response rates proved to be challenging on a technical and logistical level: the occupancy of the workspace throughout the day was not monitored by the organisation in any way and the nature of their work meant that occupants would regularly be in and out of the workspace for meetings (both on and off site). For the purpose of this study, a member of the facilities team was tasked with 
conducting a headcount during each period when a survey or performance task had been e-mailed to the occupants. This gave an indication of occupancy and therefore allowed an approximate response rate to be calculated. These counts were conducted for the first three weeks of the intervention period, the results of which are shown in Figure 21.

It is evident that the surveys consistently received higher response rates than any of the performance tasks, and the Stroop test was consistently the most popular type of performance task. The fact that the surveys and Stroop tests took only a couple of minutes to complete compared to the numerical and proofreading tasks which took between four and ten minutes to complete for the majority of respondents may or may not have been a significant factor influencing the occupant response rates.

It is clear that the response rates dropped over the three weeks for which data were available. Further analysis also indicated that the response rate decreased throughout the week (Monday to Friday) and throughout the day (morning to early afternoon to late afternoon).

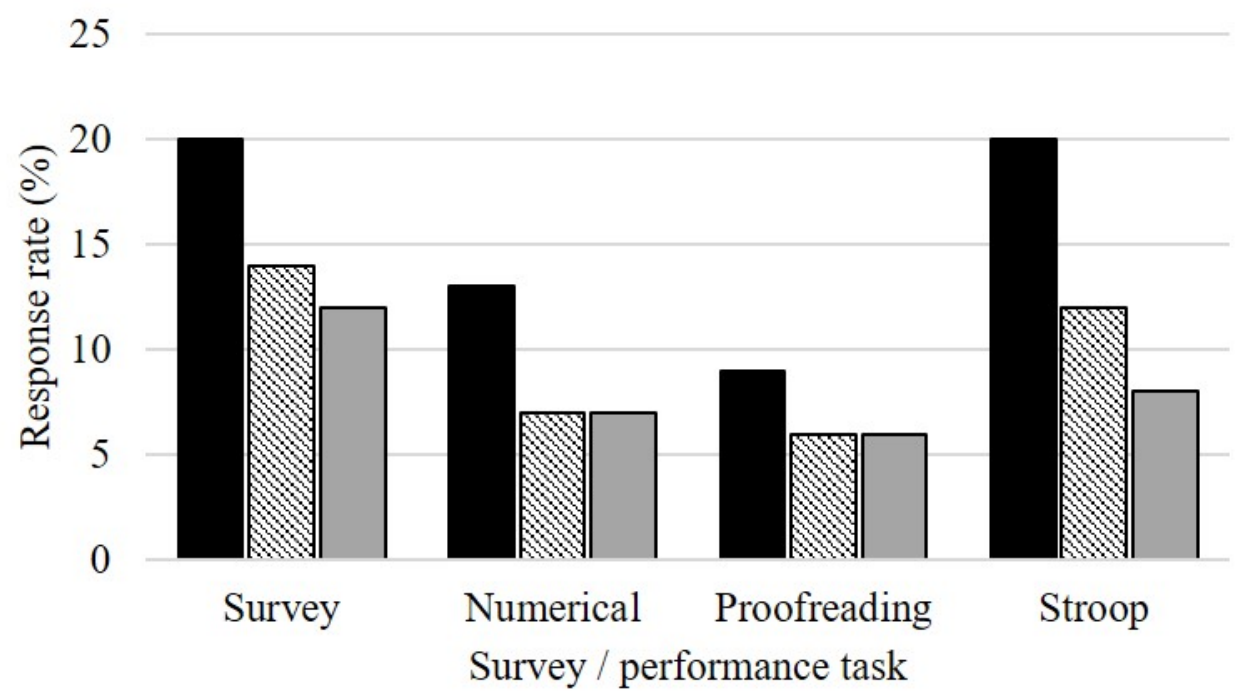

-Week 1 圆Week 2 aWeek 3

Figure 21 Weekly response rates for the surveys and performance tasks.

As surveys and performance tasks required respondents to indicate their desk number, it was possible to get an indication of how often individuals were responding (Figure 22). 
A total of 75 individuals gave responses during the intervention period. However, twenty of these only responded once, and only nine responded more than ten times.

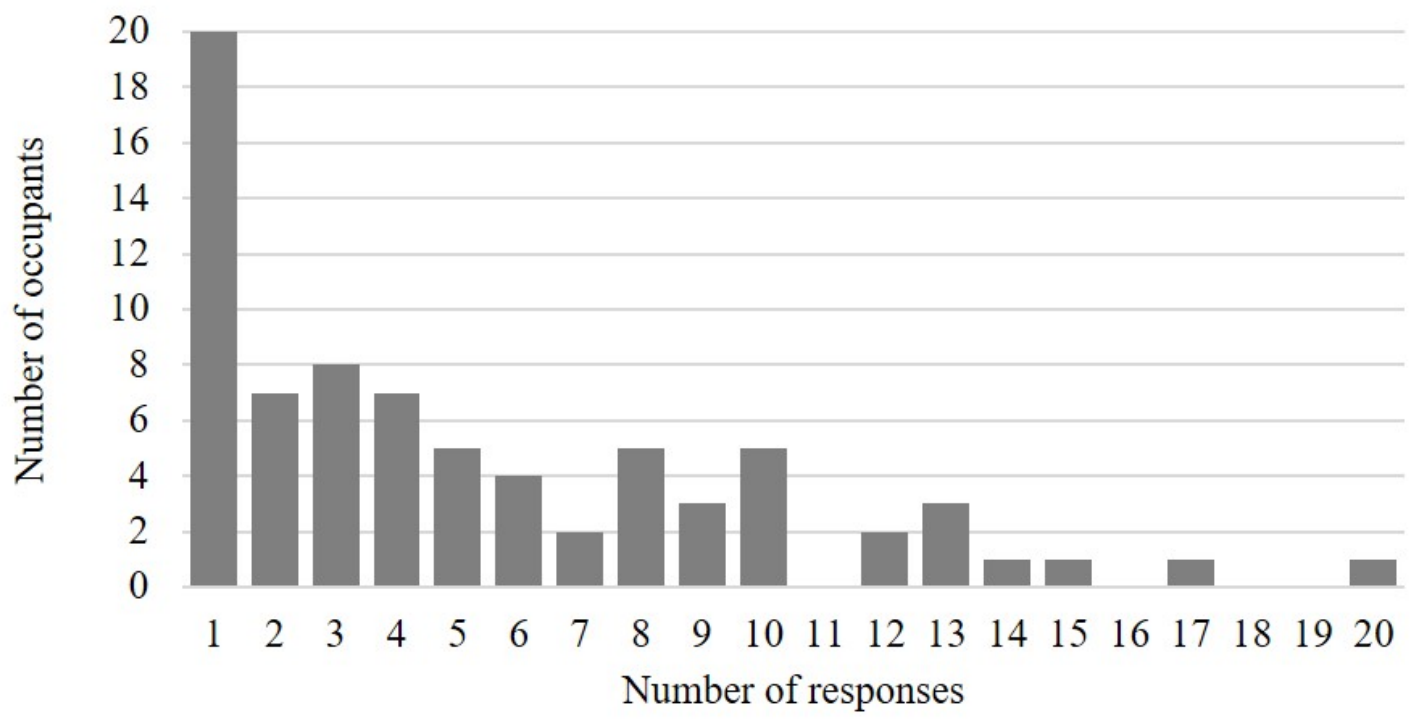

Figure 22 Number of occupants responding to surveys and tasks.

Throughout the baseline and intervention period, occupant engagement proved to be a challenge. The timings of the surveys and performance tasks were chosen so as to reduce the interruption to the occupants' working day: mid-morning when they may have been taking a short break, early afternoon when they may have been returning from a lunch break, later in the afternoon, but not too late that it interrupts work that they want to complete before the end of the day. Thought was given as to possible incentives/rewards to offer occupants for their participation. However, as responses were anonymised this would have proved difficult, and it would have also risked getting responses which were disingenuous ('speeders' who answer quickly but randomly or 'straight-liners' who answer the same for every question). Occupants were instead incentivised by being regularly thanked for their ongoing participation and reminded about the purpose of the research and the potential benefits to them in the longer term in terms of potential improvements to their working environment. 
Nevertheless, the response rates were only around $10-15 \%$ for the surveys and $5-10 \%$ for the tasks, highlighting the challenge of actively engaging participants who had been recruited to the project due to the fact that they were occupants in the case study workspaces, and were expected to participate in the study at the same time as conducting their regular daily workload. However, the essence of this project was to study occupants in their natural working environment, so the challenge of engagement was inherent in the process.

\section{Discussion}

This study has discovered interesting results through environmental monitoring, occupant surveys and performance tasks in the case study building, during the baseline and intervention periods. The building's BMS ensured that the workplace operated within relatively ranges of temperature $\left(22-25^{\circ} \mathrm{C}\right), \mathrm{RH}(25-55 \%)$ and $\mathrm{CO}_{2}$ concentration (below $1000 \mathrm{ppm}$ ) for the majority of working hours.

Although indoor temperatures had a moderate correlation with outdoor temperatures, they remained stable throughout the working day: a large change in outdoor temperature would correspond to only a small change in indoor temperature. It was also observed during the $\mathrm{CO}_{2}$ intervention (May-June 2018) that profiles of $\mathrm{CO}_{2}$ concentration were not much different whether the set-points were 1200 ppm or 1500 ppm, suggesting that energy could be saved by having more relaxed set points without compromising levels of $\mathrm{CO}_{2}$ significantly.

Although no strong correlations were observed between measured indoor environment (particularly temperature and $\mathrm{RH}$ ) and perceived or measured productivity, the proportion of occupants who expressed discomfort due to feeling too cool ( $6 \%$ and $14 \%$ in the baseline and intervention periods respectively), too warm ( $21 \%$ and $16 \%$ in 
the baseline and intervention periods respectively), or air feeling too stuffy (55\% and $52 \%$ in the baseline and intervention periods respectively), also perceived their productivity to decrease. Perceived changes in productivity were found to have much stronger links to perceived thermal sensation and perceived air quality than to actual measured temperature, $\mathrm{RH}$ and $\mathrm{CO}_{2}$ concentration. These results suggest that an occupant's experience of their environment can have a greater impact on their perceived productivity, indicating the need to consider occupants' needs and expectations when optimising indoor environments of workplaces.

Test scores and durations were used as a proxy measure of productivity. While in the baseline period, there was a weak correlation between indoor temperature and test score (though not statistically significant at the 0.05 level) which indicated that higher temperatures were linked to lower test scores, during the intervention periods, proofreading tests scores conducted at $\mathrm{CO}_{2}$ concentrations below $800 \mathrm{ppm}$ corresponded a median test score of $94 \%(n=11)$ compared to $79 \%(n=60)$ for those conducted above $800 \mathrm{ppm}$. Neither the numerical nor particularly the Stroop test were able to provide the distribution of test scores and test durations required to be able to make any statistically significant links between these datasets and concurrent indoor environment measurements. Throughout the study, no statistically significant differences were found between genders or for respondents in different age categories.

It is worth noting that, although no direct relationship was found between $\mathrm{RH}$ and either perceived or measured productivity, the low levels experienced in the building (below the recommended $40 \%$ RH for $66 \%$ of working hours during the heating season) were attributed by some occupants as contributing to dry throats, dehydration, dry skin and the spreading of germs. Quotes from the BUS questionnaire included, "Air con drys [sic.] me out. Drink a lot more water. Dry throat. Germs spread 
so end up getting illness that's going around", “The air quality, being dry, is cause for concern" and "My skin is very dry because of the low humidity. I often suffer irritable skin as a result". Although these detrimental effects on health were not monitored as part of this research project, they may indirectly have a negative impact on productivity.

Conducting this research in a real-world working office environment posed a number of challenges, particularly in terms of occupant engagement and data gathering: response rates for the surveys fell from $17 \%$ during the baseline period to $7 \%$ during the second intervention period; response rates for the tasks fell from $13 \%$ during the baseline period to $4 \%$ during the second intervention period. The proofreading tasks proved to be the least popular of the three task types, possibly because they took longer to complete and were more difficult. However, as the results have shown, having easier tasks that take less time to complete may improve the response rates, but it produces datasets which do not have sufficiently well distributed results to allow meaningful relationships with indoor environmental parameters to be found. Operating in a realworld working office environment also allows a great deal of 'noise' in the data, as a myriad of mitigating factors may influence the results.

\section{Conclusion}

This paper has adopted a case study-based approach to empirically explore the relationship between indoor environment and workplace productivity in a mechanicallyventilated office environment located in the south of England. Through continuous physical monitoring, occupant surveys and performance tasks, the study has revealed a relationship between the indoor environment and both occupant perception of their productivity and their measured productivity (using performance tasks as a proxy measure for cognitive capability, speed and accuracy). While task performance was 
affected by indoor environmental conditions such as $\mathrm{CO}_{2}$ concentration, it is clear that occupant perception of their indoor environment matters for improving productivity.

Occupants in the case study were busy with their own work and asking them to complete performance tasks over a few weeks was not easy; deep and ongoing engagement was necessary which can be resource intensive. Since many organisations are not able to define and track metrics for productivity, occupant surveys could provide a 'quick and low cost' way to gather data on perceived change in productivity in relation to the indoor environment. Such occupant surveys can also be deployed in building performance evaluation studies, and also investigations into occupant health and well-being. Performance tasks could be delivered to a subset of occupants (perhaps identified by their enthusiasm) to measure their productivity in terms of cognitive capability, speed and accuracy.

Since the research presented here is based on a single case study, there are limitations in drawing general conclusions on the link between indoor environment and workplace productivity in modern UK office buildings. Nevertheless, the methods and findings presented here can be rolled out more widely to provide a more comprehensive coverage of UK offices. Despite the challenges faced in conducting this research in a real-world working environment, evidence gathered in the study suggests that elements of indoor environment (specifically $\mathrm{CO}_{2}$ concentration) are associated with workplace productivity. It is therefore possible that effective management of the indoor environment could potentially lead to improvements in workplace productivity.

\section{Acknowledgements}

The authors would like to thank EPSRC (Grant ref: EP/N509000/1) and Innovate UK (Application number: 54815-413475) for funding the WLP+ research project under the 
Building Whole-Life Performance competition. The authors are grateful to LCMB (lead industry partner), King's College London and Emcor (project partners) for their efforts with occupant engagement. The authors are also thankful to Jonida Murataj and Dr Adorkor Bruce-Konuah for their assistance in data collection.

\section{Declaration of interest}

No conflict of interest.

\section{References}

Al Horr, Yousef, Mohammed Arif, Amit Kaushik, Ahmed Mazroei, Martha Katafygiotou, and Esam Elsarrag. 2016. "Occupant productivity and office indoor environment quality: A review of the literature." Building and Environment 105:369-89.

Alker, John, Michelle Malanca, C Pottage, and R O'Brien. 2014. "Health, wellbeing \& productivity in offices: The next chapter for green building." World Green Building Council.

Allen, Joseph G, Piers MacNaughton, Usha Satish, Suresh Santanam, Jose Vallarino, and John D Spengler. 2015. "Associations of cognitive function scores with carbon dioxide, ventilation, and volatile organic compound exposures in office workers: a controlled exposure study of green and conventional office environments." Environmental health perspectives 124 (6):805-12.

BCO. 2017. "Defining and measuring productivity in offices." In. London, UK: British Council of Offices.

Browning, Bill. 2016. "Biophilia, buildings, and your brain." People and Strategy 39 (2):8.

BUS. 2019. "Occupant satisfaction evaluation." BUS Methodology, Accessed 25 April. https://busmethodology.org.uk/.

CIBSE. 2015. "Environmental Design, CIBSE guide A." In CIBSE guide A. London. Coggon, David, Georgia Ntani, Keith T Palmer, Vanda E Felli, Raul Harari, Lope H Barrero, Sarah A Felknor, David Gimeno, Anna Cattrell, and Consol Serra. 2013. "Disabling musculoskeletal pain in working populations: is it the job, the person, or the culture?" PAIN® 154 (6):856-63.

Delos Living, LLC. 2016. "The WELL Building Standard." Retrieved July 6:2018.

Fang, Lei, David Peter Wyon, Geo Clausen, and Povl Ole Fanger. 2004. "Impact of indoor air temperature and humidity in an office on perceived air quality, SBS symptoms and performance." Indoor air 14:74-81.

Federspiel, C.C., G. Liu, M. Lahiff, D. Faulkner, D. L. DiBartolomeo, W. J. Fisk, P. Price, and D. Sullivan. 2004. Worker performance and ventilation: analyses of individual data for call center workers. Building Science: Papers from Indoor Air 2002. Previously included in Proceedings, Indoor Air 2002, Monterey, CA, June.

Gupta, Rajat, Tom Cudmore, and Adorkor Bruce-Konuah. 2016. "Desktop investigation to examine the relationship between indoor environmental conditions and productivity in work spaces." Investigating market demand and supply of construction industry waste as:207. 
Kajtar, L, L Herczeg, and E Lang. 2003. "Examination of influence of CO2 concentration by scientific methods in the laboratory". Proceedings of healthy buildings, vol. 3, pp. 176-181. 2003.

Korolija, Ivan, Ljiljana Marjanovic-Halburd, Yi Zhang, and Victor I Hanby. 2013. "UK office buildings archetypal model as methodological approach in development of regression models for predicting building energy consumption from heating and cooling demands." Energy and Buildings 60:152-62.

Lan, Li, Pawel Wargocki, David Peter Wyon, and Zhiwei Lian. 2011. "Effects of thermal discomfort in an office on perceived air quality, SBS symptoms, physiological responses, and human performance." Indoor air 21 (5):376-90.

ONS. 2014. "Long tem sickness absence." Office for National Statistics, Accessed 25th April 2019. https://www.gov.uk/government/statistics/long-term-sicknessabsence. . 2018. "International comparisons of UK productivity (ICP), final estimates: 2016." Office for National Statistics, Accessed 23rd April 2019. https://www.ons.gov.uk/economy/economicoutputandproductivity/productivity measures/bulletins/internationalcomparisonsofproductivityfinalestimates/2016.

Park, JS, and CH Yoon. 2011. "The effects of outdoor air supply rate on work performance during 8-h work period." Indoor air 21 (4):284-90.

Satish, Usha, Mark J Mendell, Krishnamurthy Shekhar, Toshifumi Hotchi, Douglas Sullivan, Siegfried Streufert, and William J Fisk. 2012. "Is CO2 an indoor pollutant? Direct effects of low-to-moderate $\mathrm{CO} 2$ concentrations on human decision-making performance." Environmental health perspectives 120 (12):1671-7.

Seppanen, Olli, William J Fisk, and QH Lei. 2006. "Effect of temperature on task performance in office environment." In.: Ernest Orlando Lawrence Berkeley NationalLaboratory, Berkeley, CA (US).

Shahzad, Sally, John Brennan, Dimitris Theodossopoulos, Ben Hughes, and John Calautit. 2016. "Building-related symptoms, energy, and thermal control in the workplace: personal and open plan offices." Sustainability 8 (4):331.

Smith, L, O McCourt, A Sawyer, M Ucci, A Marmot, J Wardle, and A Fisher. 2016. "A review of occupational physical activity and sedentary behaviour correlates." Occupational Medicine 66 (3):185-92.

Tanabe, Shin-ichi, Masaoki Haneda, and Naoe Nishihara. 2015. "Workplace productivity and individual thermal satisfaction." Building and Environment 91:42-50.

Tham, KW, and HC Willem. 2005. "SYMPOSIUM PAPERS-DE-05-10 Indoor Environments and Human Productivity-Temperature and Ventilation Effects on Performance and Neurobehavioral-Related Symptoms of Tropically Acclimatized Call Center." ASHRAE Transactions-American Society of Heating Refrigerating Airconditioning Engin 111 (2):687-98.

UKGBC. 2017. "Health, wellbeing and productivity in offices: The next chapter for green building." UK Green Building Council, Accessed 25th March 2019. https://www.ukgbc.org/ukgbc-work/health-wellbeing-productivity-offices-nextchapter-green-building/.

Vimalanathan, Komalanathan, and Thangavelu Ramesh Babu. 2014. "The effect of indoor office environment on the work performance, health and well-being of office workers." Journal of environmental health science and engineering 12 (1):113. 
Wargocki, Pawel, David P Wyon, Yong K Baik, Geo Clausen, and P Ole Fanger. 1999. "Perceived air quality, sick building syndrome (SBS) symptoms and productivity in an office with two different pollution loads." Indoor air 9 (3): $165-79$.

Witterseh, Thomas, David P Wyon, and Geo Clausen. 2004. "The effects of moderate heat stress and open-plan office noise distraction on SBS symptoms and on the performance of office work." Indoor air 14:30-40. 